
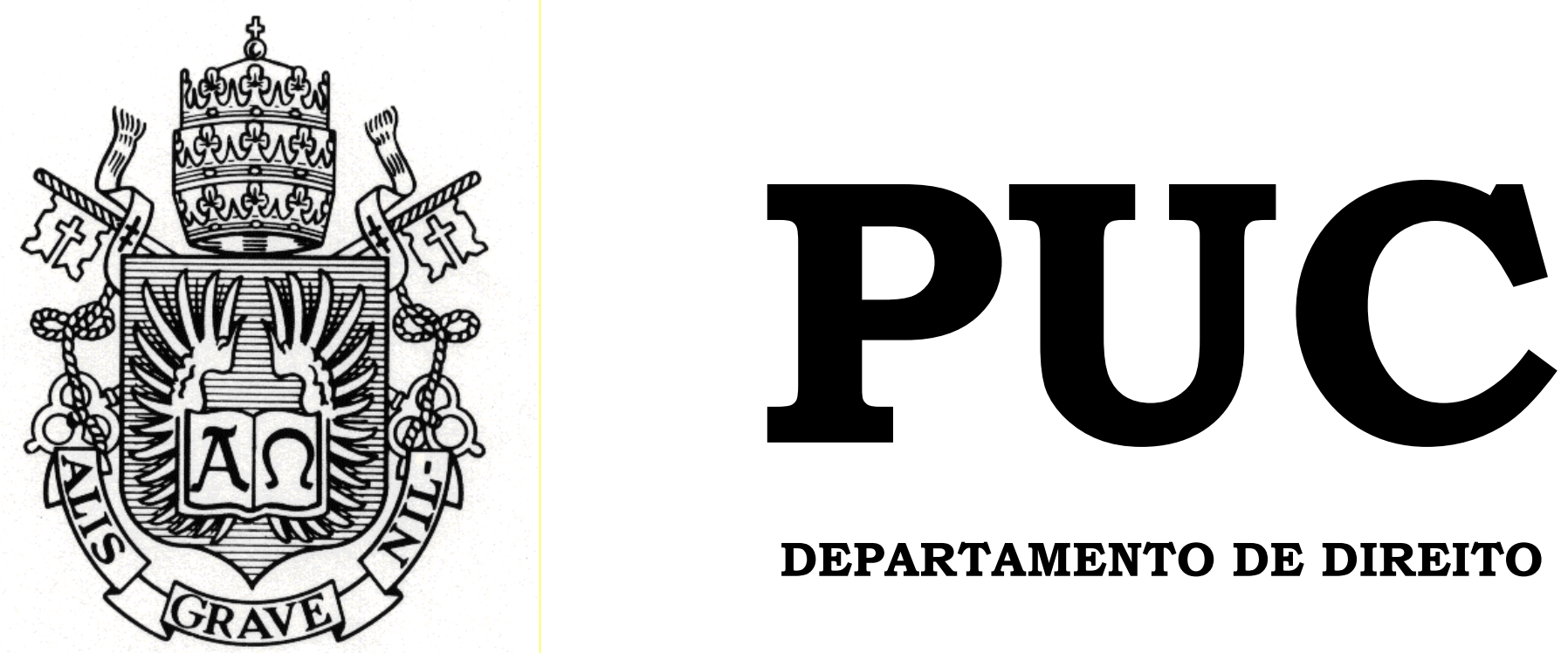

DEPARTAMENTO DE DIREITO

\title{
A Coleta de Dados pelas Novas Tecnologias e o Direito à Privacidade
}

por

LUISA FERREIRA GONZALEZ PENNA

ORIENTADOR: PEDRO MARCOS NUNES BARBOSA

2018.1

PONTIFÍCIA UNIVERSIDADE CATÓLICA DO RIO DE JANEIRO RUA MARQUÊS DE SÃO VICENTE, 225 - CEP 22453-900 RIO DE JANEIRO - BRASIL 


\section{A Coleta de Dados pelas Novas Tecnologias e o Direito à Privacidade por}

\section{LUISA FERREIRA GONZALEZ PENNA}

Monografia

apresentada

ao

Departamento de Direito da Pontificia Universidade Católica do Rio de Janeiro (PUC-Rio) para a obtenção do Título de Bacharel em Direito.

Orientador: Pedro Marcos Nunes Barbosa 


\section{Agradecimentos}

Primeiramente, gostaria de agradecer aos meus pais, pelo apoio incondicional e por nunca medirem esforços para me proporcionar tudo de melhor.

Gostaria de agradecer também o meu irmão, Daniel, por ser um incansável debatedor e um grande amigo. Tenho muito admiração por você e ter você como irmão é uma experiência muito enriquecedora.

Agradeço ao Danilo, por ser meu maior companheiro e meu melhor amigo, me apoiando e me incentivando a cada momento do nosso tempo juntos.

Agradeço também à todas as minhas amizades feitas na PUC, em especial à Gabriela Assumpção e à Giovanna Ortiz, por terem tornado esses últimos cinco anos os mais memoráveis e divertidos da minha vida. Aprendi muito com vocês e tenho a certeza de que terei vocês comigo pro resto da vida.

Por fim, agradeço imensamente ao meu orientador, Pedro Marcos Nunes Barbosa, por ter não só me proporcionado grandes ensinamentos acadêmicos, mas também de vida. Nunca tive um perfil acadêmico, mas com você eu aprendi a importância da pesquisa e adquiri um conhecimento do qual hoje sou muito feliz em tê-lo. Meu muito obrigado. 


\section{Resumo}

O presente trabalho busca tratar do direito fundamental à privacidade ante a nova estruturação da sociedade e das relações humanas pelo o uso das novas tecnologias. $\mathrm{O}$ aumento do uso das novas tecnologias as quais permitem a coleta, uso, tratamento e armazenamento de dados que podem traduzir informações sobre indivíduos, traz uma série de consequências para o âmbito da privacidade, tornando imprescindível que o direito apresente respostas regulatórias para essa nova realidade.

Palavras-chave: Novas Tecnologias. Big Data. Coleta, uso, tratamento e armazenamento de dados. Vigilância Digital. Direito à privacidade. Transmutação do conceito. Regulação. 


\section{Sumário:}

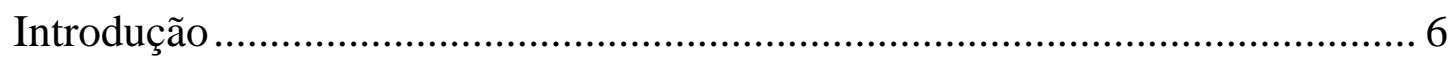

1. Novas tecnologias e a economia da informação .................................... 8

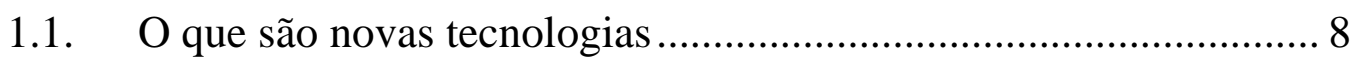

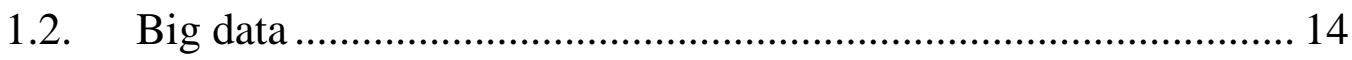

1.3. Economia da informação: a coleta e o tratamento de dados.......... 15

1.4. Vigilância digital............................................................................ 22

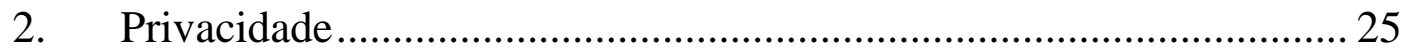

2.1. Construção histórica do termo privacidade …………………...... 25

2.2. Positivação no direito................................................................. 33

2.3. Mutação do conceito de privacidade diante da sociedade atual ... 38

3. Regulamentação da coleta de dados ..................................................... 43

3.1. A regulamentação da coleta de dados nos diplomas estrangeiros 48

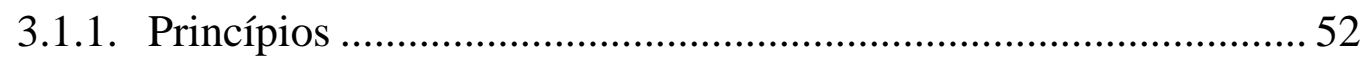

3.2. A regulamentação da coleta de dados no Brasil ............................. 55

3.2.1. O Marco Civil da Internet - Lei 12.965/2014 ............................. 57

3.2.2. Demais iniciativas legislativas (PL 330/2013 e PL 5.276/2016).. 62

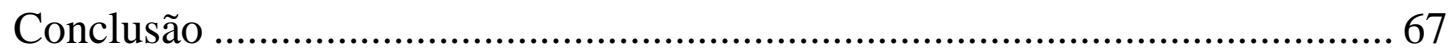

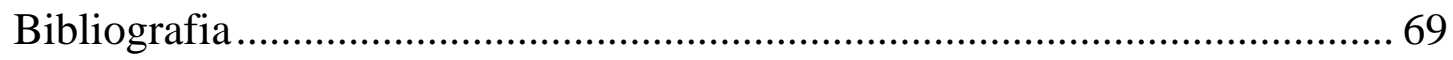




\section{Lista de abreviações}

CF - Constituição da República Federativa do Brasil de 1988

DPO - Data Protection Officer (Agente de Proteção de Dados)

FGV - Fundação Getúlio Vargas

GDPR - General Data Protection Regulation (Regulamento Geral de Proteção

de Dados)

MCI - Marco Civil da Internet

ONU - Organização das Nações Unidas

PL - Projeto de Lei

STF - Supremo Tribunal Federal 


\section{Introdução}

Mark Zuckerberg, criador e dono do Facebook, se viu este ano diante de grande escrutínio público e encarando sérias consequências legais devido à emergência do escândalo de uso de dados coletados por meio de seu aplicativo e os quais foram comercializados à empresa Cambridge Analytica - sociedade especializada em pesquisas eleitorais - com o intuito de manipular e influenciar as últimas eleições americanas. ${ }^{1}$

O escândalo vivido pelo Facebook é chocante, porém não é novo. A prática de coleta, tratamento e venda de dados de usuários de aplicativos e da Internet em geral, tem se mostrado uma prática muito comum ante a facilidade da coleta e de seu tratamento, assim como pelo fato de a informação coletada ter se tornado um dos principais bens ou commons ${ }^{2}$ do mercado.

Isso porque a coleta de dados possibilita não apenas a identificação e interpretação de certas informações, mas também a recombinação de informações que, por meio de algoritmos derivados das novas tecnologias, permitem o conhecimento por agentes privados e por Governos a respeito da dinâmica do inconsciente individual - como gostos, preferências e opiniões políticas - assim como das interações coletivas ${ }^{3}$.

Ocorre que, como mencionado no caso do Facebook, a coleta de dados passou a representar uma verdadeira ameaça ao direito fundamental à privacidade, no sentido em que a existência da disponibilidade de informação

\footnotetext{
1 COSTA, Camilla. Como descobrir o que o Facebook sabe sobre você. Disponível em <http://www.bbc.com/portuguese/geral-43493673>. Acesso em 04 de Abril de 2018.

${ }^{2}$ BENKLER, Yochai. The Wealth of Networks: How Social Production Transforms Markets and Freedom. Yale University Press, 2006. p. 60.

${ }^{3}$ PICCELLI, Roberto Ricomini. A dimensão política da privacidade no direito brasileiro. Rio de Janeiro: Lumen Juris, 2018. p. 5.
} 
pessoal pode gerar a sua exposição e utilização indevida ou mesmo abusiva por terceiros ${ }^{4}$, o que gera uma série de questionamentos para o campo do direito.

Assim, diante do crescente papel desempenhado pelas novas tecnologias sobre a sociedade atual, com a transposição de todos os tipos de relacionamentos para a Rede, torna-se necessário analisar algumas questões que resultam do uso intensificado de tais instrumentos, como a proteção do direito à privacidade.

Dessa forma é que o presente estudo visa abordar o surgimento das denominadas novas tecnologias e as suas implicações para a dinâmica social, principalmente no que tange o direito à privacidade.

Para tanto, primeiro se irá abordar o surgimento das novas tecnologias, suas características principais e como delas resultou um novo modelo de negócio que revolucionou a economia, fazendo surgir a economia informacional e a problemática da vigilância digital.

Em seguida, será retratado o direito à privacidade, fazendo-se uma análise do seu desenvolvimento histórico, a sua positivação nos diplomas legais nacionais e internacionais para ao final afirmar a transformação do conceito de direito à privacidade ante as atuais transformações da própria sociedade.

Por fim, ante a problemática exposta, será analisada a necessidade de uma regulamentação para a matéria, dissecando certos princípios já estabelecidos para nortear a proteção de dados na rede, bem como se analisando os sistemas já existentes para a proteção contra a abusiva coleta e uso de dados em diversos países, inclusive no Brasil.

\footnotetext{
${ }^{4}$ DONEDA, Danilo. O Direito Fundamental à Proteção de Dados Pessoais. In: MARTINS, Guilherme Magalhães (Org.). Direito Privado e Internet. São Paulo: Editora Atlas, 2014. p. 61.
} 


\section{Novas tecnologias e a economia da informação}

\subsection{0 que são novas tecnologias}

A definição tradicional do termo "tecnologia" engloba o conhecimento técnico e científico e a aplicação deste conhecimento através de sua transformação no uso de ferramentas, processos e materiais criados e utilizados a partir de tal conhecimento.

A partir dessa definição, é fácil constatar que os utensílios e processos considerados mais rudimentares, são sim, tecnologias. Um garfo pode ser considerado uma tecnologia, assim como o processo de ferver água também é considerado como a aplicação de uma tecnologia.

Nesse sentido é que se pode afirmar que o surgimento de diferentes tecnologias ao longo da história, sem dúvidas, contribuiu para a evolução da humanidade e, foi essencial para diversos desdobramentos históricos.

No entanto, como abordou Pierre Lévy em sua obra "Cibercultura", as tecnologias não podem ser entendidas como fatores determinantes de uma sociedade, mas sim como fatores condicionantes. Isso significa que, a tecnologia, por si só, não é responsável por fatos sociais e culturais, já que é o uso humano que atribuído à ela que é determinante. ${ }^{5}$

Tal observação também é feita por Manuel Castells ${ }^{6}$ e Yochai Benkler, $^{7}$ tendo estes ressaltado que embora as tecnologias não determinem a evolução histórica de uma sociedade, elas possuem sim a capacidade de influenciá-la de forma decisiva, contribuindo para a sua transformação.

\footnotetext{
${ }^{5}$ LÉVY, Pierre. Cibercultura. Tradução de Carlos Irineu da Costa. $3^{a}$ ed. São Paulo: Editora 34, 2011. p. 25-27.

${ }^{6}$ CASTELLS, Manuel. A sociedade em rede. Tradução de Roneide Venancio Majer. $18^{\mathrm{a}}$ ed. São Paulo: Paz e Terra, 2017. p. 64.

${ }^{7}$ BENKLER, Yochai. The Wealth of Networks: How Social Production Transforms Markets and Freedom. Yale University Press, 2006. p. 30.
} 
Desse modo é que se entende as tecnologias como condicionantes do processo evolutivo da sociedade em diversos aspectos, contudo não pode ser a tecnologia considerada determinante no sentido em que irá definir o futuro da sociedade.

Castells ainda observa que não são apenas as tecnologias que influenciam a sociedade. A própria sociedade em si, com as suas características sociais, econômicas e culturais particulares de cada época, propiciam a proliferação e o surgimento de diferentes tecnologias. Sendo assim, a relação entre a tecnologia e o desenvolvimento da sociedade é ambivalente. ${ }^{8} 9$

Assim é que as tecnologias não podem ser compreendidas como essencialmente positivas ou negativas, sendo equivocada a tentativa de alguns em "refreá-las". As tecnologias são condicionantes no sentido em que dão à sociedade uma gama de possibilidades para a formação de padrões sociais e culturais, mas que não são capazes de determiná-los.

Pois bem. No que tange especificamente as ditas novas tecnologias, presentes desde o final do século XX, deve-se ter em mente que essas são produtos do surgimento da internet ou da $\operatorname{Rede}^{10}$, que, em definição técnica, consiste em uma "rede aberta decorrente da conexão de várias redes entre si, perfazendo-se a

\footnotetext{
${ }^{8}$ CASTELLS, Manuel. A sociedade em rede. Tradução de Roneide Venancio Majer. $18^{a}$ ed. São Paulo: Paz e Terra, 2017. p. 65.

${ }^{9}$ Como bem colocou o mestre Pedro Marcos Nunes Barbosa em sua mais recente obra, a qual aborda a relação dos estabelecimentos comerciais com a Rede, a tecnologia "apesar de protagonizar transformações mercantis operadas online, foi o conjunto social-contextual (que ocorreu simultaneamente à popularização da internet) que determinou a nova faceta do comércio internacional." BARBOSA, Pedro Marcos Nunes. E-stabelecimento: teoria do estabelecimento comercial na internet, aplicativos, websites, segregação patrimonial, trade dress eletrônico, concorrência online, ativos intangíveis cibernéticos e negócios jurídicos. São Paulo: Quartier Latin, 2018. p. 29.

${ }^{10}$ Manuel Castells, ao tratar do surgimento da internet, afirma que esta se trata de uma rede que não é passível de controle a partir de nenhum centro, sendo composta por milhares de redes autônomas e com inúmeras maneiras de conexão. CASTELLS, Manuel. A sociedade em rede. Tradução de Roneide Venancio Majer. 18 a ed. São Paulo: Paz e Terra, 2017. p. 65.
} 
comunicação por meio de um conjunto de protocolos denominados Transmission Control Protocol/Internet Protocol (TCP/IP)"11 12.

A internet foi primeiramente concebida após a Segunda Guerra Mundial, de início denominada "ARPANET", para posteriormente se transformar em "World Wide Web", presente até os dias de hoje.

Devido ao momento vivido quando foi concebida, a internet devia ter como característica principal uma arquitetura descentralizada. Usada primeiramente para fins militares, era essencial que não houvesse um centro de controle ou computador central para a troca de informações, visto que a descentralização possibilita a preservação dos demais e, assim, possibilita a manutenção da troca de informações. ${ }^{13}$

Após a Guerra, a internet deixou de ter como única finalidade o auxílio nas operações militares para servir também à fins acadêmicos. Contudo, foi só em 1994 que o acesso à Rede foi disponibilizado a todos.

Cumpre destacar que, como apontaram Paula Forgioni e Maira Miura, a internet - diferentemente dos meios tradicionais de comunicação - não é baseada em um meio unidirecional de informação, muito pelo contrário, a internet é multidirecional, o que possibilita ao usuário receber as mais diversas informações, sem a existência de um centro de controle que as pré-determine.

Além disso, a internet também se distingue dos demais meios de comunicação no sentido que incentiva a troca contínua de informações entre os

\footnotetext{
${ }^{11}$ MARTINS, Guilherme Magalhães. Responsabilidade civil por acidente de consumo na Internet. São Paulo: Ed. RT, 2008. p. 30.

12 O Marco Civil da Internet, Lei 12.965/2014 apresentou em seu art. 5º, inciso I, uma definição semelhante, afirmando-se internet como "um sistema constituído do conjunto de protocolos lógicos, estruturado em escala mundial para uso público e irrestrito, com a finalidade de possibilitar a comunicação de dados entre terminais por meio de diferentes redes".

${ }^{13}$ FILHO, Eduardo Tomasevicius. O Marco Civil da Internet e as Liberdade de Mercado. In: LUCCA, Newton; FILHO, Adalberto Simao; LIMA, Cintia Rosa Pereira (Org.). Direito \& Internet III: Marco Civil da Internet (Lei 12.965/2014). Tomo II. São Paulo: Quartier Latin, 2015. p. 49.
} 
usuários da Rede, permitindo que o usuário seja tanto receptor de informações como criador delas. ${ }^{14}$

Assim é que a Internet é uma forma de mídia que quebrou paradigmas e se distingue de forma exponencial das demais mídias até antes conhecidas. Ao contrário das mídias tradicionais, como rádio e televisão, nas quais o espectador tem um caráter essencialmente passivo; na Internet, ao espectador é possível criar uma interação com o meio, havendo assim uma participação ativa do indivíduo, que deixa de ser apenas espectador para se tornar também um criador de conteúdo de obras coletivas. ${ }^{15}$

Desse modo, foi que a internet, envisionada assim como um meio de comunicação independente de centros de controle, forneceu a estrutura necessária para uma troca de informação e mensagens de alcance global.

Foi essa estrutura que permitiu o que Pierre Lévy afirmou ser o "ciberspaço", isto é, um ambiente novo de comunicação o qual se destaca pela sua acentuada interatividade e pelo seu caráter comunitário, no sentido em que contribui para o advento de uma inteligência coletiva. ${ }^{16} 17$

Nesse sentido, as novas tecnologias são, para Lévy, as interações entre diversos grupos que realizam trocas de informações dando espaço para a criação de um conhecimento compartilhado em escala mundial, estando tal conhecimento amparado em formato digital, isso é, em um formato extremamente fluido.

\footnotetext{
${ }^{14}$ FORGIONI, Paula A.; MIURA, Maira Yuriko Rocha. O Princípio da Neutralidade e o Marco Civil da Internet no Brasil. In: LUCCA, Newton; FILHO, Adalberto Simao; LIMA, Cintia Rosa Pereira (Org.). Direito \& Internet III: Marco Civil da Internet (Lei 12.965/2014). Tomo II. São Paulo: Quartier Latin, 2015. p. 111.

${ }^{15}$ BARBOSA, Pedro Marcos Nunes. E-stabelecimento: teoria do estabelecimento comercial na internet, aplicativos, websites, segregação patrimonial, trade dress eletrônico, concorrência online, ativos intangíveis cibernéticos e negócios jurídicos. São Paulo: Quartier Latin, 2018. p. 58-59.

${ }^{16}$ LÉVY, Pierre. Cibercultura. Tradução de Carlos Irineu da Costa. $3^{a}$ ed. São Paulo: Editora 34, 2011. p. 29.

${ }^{17}$ Lévy posteriormente faz uma definição mais técnica do que seria o ciberespaço, ao afirmar que este seria "o espaço de comunicação aberto pela interconexão mundial dos computadores e das memórias dos computadores. ” LÉVY, Pierre. Cibercultura. Tradução de Carlos Irineu da Costa. $3^{\text {a }}$ ed. São Paulo: Editora 34, 2011.p. 94.
} 
$\mathrm{O}$ fato de a denominada inteligência coletiva se encontrar em formato digital é de extrema relevância, visto que foi com o advento da digitalização das informações que foi possível a ascensão do ciberespaço. Isso ocorre porque, como bem apontou o filósofo, a digitalização, que traz a possibilidade de transmissão de mensagem de forma precisa, tratável, em tempo real e de forma interativa, induz para um aumento das trocas de informações no ciberespaço, tornando-o o principal meio de comunicação da atualidade.

Dessa forma, a digitalização das informações foi crucial para a revolução tecnológica a qual se está tratando, tendo em vista que o surgimento do computador e da Rede, com a possibilidade de digitalizar informações com um alto grau de exatidão e interatividade, torna a informação onipresente ${ }^{18}$.

Desse modo, a rede e a digitalização das informações permitiram o chamado "dilúvio das telecomunicações" no qual se tem a proliferação do trânsito de informações e uma consequente "inundação" de dados de forma exponencial e anárquica. ${ }^{19}$

Lévy ainda destaca que as novas tecnologias, ou melhor, tecnologias digitais, estruturam o ciberespaço de um modo que incentivam a comunicação, a sociabilidade e, por fim, também oportunizaram um novo mercado da informação.

Assim, a informação, agora em formato digital, descentralizou-se, diversificou-se e democratizou-se, facultando aos usuários cada vez mais uma maior interação com as informações ${ }^{20}$.

Dito isso, foi com o surgimento da internet que foi dado início à uma nova revolução tecnológica, com grandes implicações na sociedade e cujos impactos ainda não podem ser mensurados.

\footnotetext{
${ }^{18}$ DONEDA, Danilo. Da Privacidade à Proteção de Dados Pessoais. Rio de Janeiro: Renovar, 2006. p. 175.

${ }^{19}$ LÉVY, Pierre. Cibercultura. Tradução de Carlos Irineu da Costa. $3^{\text {a }}$ ed. São Paulo: Editora 34, 2011. p. 13-15.

${ }^{20}$ LEONARDI, Marcel. Tutela e privacidade na Internet. São Paulo: Saraiva, 2011. p. 28.
} 
Com surgimento das denominadas novas tecnologias, as quais também são definidas pelo professor William Fisher III $^{21}$ como a transformação de conteúdo analógico para o digital, é que se tornou possível a troca de informações em uma velocidade e alcance nunca antes visto.

O professor Eduardo Magrani traduz bem esse fato, ao afirmar ${ }^{22}$ :

"a tecnologia digital, combinada com a infraestrutura da internet, se distingue de maneira substantiva das tradicionais mídias. Trata-se de uma plataforma de comunicação de duas vias, através da qual participantes não são meros receptores passivos de conteúdo. A importância dessas ferramentas digitais é possibilitar a criação de um novo ambiente comunicativo, que permite a qualquer um, a um preço muito mais acessível do que no passado recente, transmitir suas ideias com uma facilidade sem precedentes."

Nesse sentido é que é possível afirmar que a internet alterou substancialmente a sociedade e as relações humanas, sendo o compartilhamento de informações o seu principal objetivo. ${ }^{23}$

Um dos primeiros juristas a antecipar a transposição das relações do mundo real para o mundo virtual, ou mundo em rede, foi Cass R. Sustein que, pioneiramente em sua obra "Republic.com" - com a posterior revisão da referida obra em "Republic.com 2.0" - abordou como a tecnologia digital provocou uma mudança radical no convívio social, provocando mudanças de paradigmas.

Atualmente, grande parte das trocas de informações se dá dentro da rede ou do ciberespaço, ambiente descentralizado por natureza, como já afirmado. A possibilidade de poder receber, em escala global, os mais variados conhecimentos e, do mesmo modo, poder também fornecer a outros suas opiniões, palavras e sentimentos, se torna cada vez mais algo inerente à sociedade atual.

\footnotetext{
${ }^{21}$ FISHER III, William W. Promises to Keep: Technology, Law, and the Future of Entertainment. California: Stanford University Press, 2004. p. 13-14.

${ }^{22}$ MAGRANI, Eduardo. Democracia conectada: a internet como ferramenta de engajamento políticodemocrático. Curitiba: Juruá, 2014. p. 57.

${ }^{23}$ SCHERKERKEWITZ, Iso Chaitz. Direito e Internet. São Paulo: Revista dos Tribunais, 2014. p. 15.
} 
Nesse sentido é que se pode ter um panorama de como as novas tecnologias - que no presente trabalho englobam a digitalização da informação, a infraestrutura da rede e a sua característica de interatividade e de troca de mensagens de forma precisa - transformaram completamente a concepção de comunicação e da própria interação social.

Para o presente estudo, contudo, a análise pertinente deve se esmiuçar no fenômeno da "Big Data" e as suas implicações para o direito à privacidade.

\subsection{Big data}

"Big Data" é um termo que carece de uma definição precisa, porém, em linhas gerais, pode ser definido como um conglomerado de dados - que não se confunde com informações ${ }^{24}$ - em grande volume, estruturados e não estruturados, que cada vez mais impactam os negócios e transações comerciais cotidianamente. ${ }^{25}$

Tal conglomerado de dados constitui hoje um dos maiores ativos no mercado, deixando de ser apenas um fator auxiliar na produtividade da era da

\footnotetext{
${ }^{24}$ A respeito da diferença existente entre os termos "dado" e "informação", cumpre mencionar a distinção feita por Cristina Sílvia Alves Lourenço e Maurício Sullivan Balhe Guedes, que afirmam que o dado seria apenas um complexo lógico de símbolos quantitativos e qualitativos que, depois de uma análise interpretativa, resultariam na informação. LOURENÇO, Cristina Sílvia Alves; GUEDES, Maurício Sullivan Balhe, A internet e o direito à exclusão de dados pessoais na experiencia brasileira. In: LEITE, George Salomão; LEMOS, Ronaldo (Org.). Marco Civil da Internet. São Paulo: Atlas, 2014. p. 559. Essa distinção também é feita por Danilo Doneda, que afirma ter o dado uma conotação mais primitiva, como se fosse uma informação em potencial. Já a informação transmite algo além do dado, chegando ao limiar da cognição. DONEDA, Danilo. O direito fundamental à proteção de dados pessoais. In: MARTINS, Guilherme Magalhães. (Org.). Direito Privado e Internet. São Paulo: Atlas, 2014. p. 63. Desse modo, se entende que a informação, portanto, precisa do dado aliado a um tipo de cognição, sendo o dado uma espécie de pré-informação.

25 Apesar de não se ter uma definição precisa do termo, cumpre ressaltar que os elementos caracterizadores da "Big data" foram primeiramente estabelecidos por Doug Laney, que afirmou a necessidade dos três V`s: Volume, velocidade e variedade. DIEBOLD, Francis X. On the Origin(s) and Development of the Term 'Big Data'. PIER Working Paper No. 12-037, PENN Institute for Economic Research, set. 2012. p. 4.
} 
economia industrial, para se tornar, a partir da década de 90 , um produto por si só, como pontuou Manuel Castells. ${ }^{26}$

No estudo mencionado, Castells aponta a diferença existente entre os impactos tecnológicos referentes à dois períodos de tempo. Entre o surgimento da Rede, após a Segunda Guerra Mundial, até os anos 70, é possível perceber que os avanços tecnológicos elevaram de forma exponencial a produtividade de diversos países, constituindo a tecnologia criada um verdadeiro fator determinante da capacidade produtiva.

Ocorre que, a partir da década de 70, tal aumento da produtividade não é mais percebido, verificando-se até uma estagnação, a qual Manuel Castells procura explicar apresentando estudos econômicos que atribuem à impossibilidade de uma absorção tão rápida das inovações tecnológicas pela sociedade, não tendo sido assim possível à sociedade o acompanhamento do surgimento de tecnologias com a sua aplicação na produtividade ${ }^{27}$.

No entanto, a partir da década de 90 é que a tecnologia novamente vem a afetar a sociedade de forma drástica, dando-se início à substituição da evidência da economia industrial para a economia informacional. ${ }^{28}$

\subsection{Economia da informação: a coleta e o tratamento de dados}

A denominada economia informacional ou economia da informação é um termo que passou a ser usado a partir da década de 70 para denominar a crescente

\footnotetext{
${ }^{26}$ CASTELLS, Manuel. A sociedade em rede. Tradução de Roneide Venancio Majer. $18^{\mathrm{a}}$ ed. São Paulo: Paz e Terra, 2017. p. 135.

${ }^{27}$ CASTELLS, Manuel. A sociedade em rede. Tradução de Roneide Venancio Majer. $18^{\mathrm{a}}$ ed. São Paulo: Paz e Terra, 2017. p. 142-143.

${ }^{28}$ BARBOSA, Marco A. Marco Civil da Internet: Mercado e Estado de Vigilância. In: LUCCA, Newton; FILHO, Adalberto Simão; LIMA, Cintia Rosa Pereira (Org.). Direito \& Internet III: Marco Civil da Internet (Lei 12.965/2014). Tomo II São Paulo: Quartier Latin, 2015. p. 246. O termo "economia informacional" também foi utilizado por Manuel Castells na obra "A Sociedade em Rede", atribuindo ainda a essa nova economia as características de ser global e em rede. CASTELLS, Manuel. A sociedade em rede. Tradução de Roneide Venancio Majer. 18ª ed. São Paulo: Paz e Terra, 2017. p. 135.
} 
e exponencial importância que as informações - de todos os tipos - passaram a desempenhar junto ao mercado, auxiliando nos meios de controle de produção e melhorando a produtividade. ${ }^{29}$

A economia informacional é um produto da era da informação, na qual se operou a quebra de certos paradigmas presentes na era industrial, como a própria função da informação, que no atual momento passou a representar um ativo econômico por si só. ${ }^{30}$

A economia informacional surgiu, portanto, a partir da década de 70 , tendo se consolidado de fato na década de 90. Buscando explicar sua origem, Andrew Keen afirma que a economia informacional é um produto do libertarismo selvagem característico dos anos 60 , no qual prevalecia a ideia de resistência à hierarquia e ao controle centralizado, tendo-se uma preferência pela transparência e pela ideia do comunitarismo. ${ }^{31}$

Tais ideias dos anos 60 impulsionaram o surgimento da Rede e do ciberespaço que, como já abordado anteriormente, é naturalmente um ambiente descentralizado e com alta interatividade.

O surgimento da Rede, com seu alto fluxo de informações devido à interatividade e o seu caráter comunitário, deu abertura assim para um novo tipo de modelo econômico baseado nas informações transmitidas pela Rede, as quais deixaram de ter como função única o aumento da produtividade industrial percebida até os anos 70 .

\footnotetext{
${ }^{29}$ BENKLER, Yochai. The Wealth of Networks: How Social Production Transforms Markets and Freedom. Yale University Press, 2006. p. 31.

${ }^{30}$ BARBOSA, Pedro Marcos Nunes. E-stabelecimento: teoria do estabelecimento comercial na internet, aplicativos, websites, segregação patrimonial, trade dress eletrônico, concorrência online, ativos intangíveis cibernéticos e negócios jurídicos. São Paulo: Quartier Latin, 2018. p. 21.

${ }^{31}$ KEEN, Andrew. Vertigem Digital: Por que as redes sociais estão nos dividindo, diminuindo e desorientando. Edição Kindle. Tradução Alexandre Martins. Editora Zahar, 2012. cap. 5, posição 1949.
} 
Este novo modelo econômico se coadunou com uma nova mentalidade humana: a de um indivíduo autodeterminado e individualizado, o qual buscava fazer parte da contracultura, compartilhando informações por meio da Rede ${ }^{32}$.

O grande fluxo de troca de informações passou, portanto, a desempenhar papel fundamental na ascensão desse novo modelo econômico, transformando uma economia baseada no comércio para uma economia dominada pela troca de informação, na qual os dados trocados e as informações por eles exprimidas passaram a possuir valor econômico.

A valorização das informações colhidas pela Rede foi tão marcante para o final do século XX e início do século XXI que o professor Yochai Benkler intitulou a sua obra "The Wealth of Networks"33 ("A Riqueza das Redes") com o intuito de exatamente expressar a ideia da informação como o mais novo meio de riqueza, representando a instauração da economia informacional.

A economia baseada na informação representou uma verdadeira mutação das sociedades empresárias e suas hierarquias, visto que agora possuíam novos meios de comunicação e recursos para a obtenção de informações a respeito do público consumidor.

Recursos como os de obtenção de informações a respeito da correlação entre mulheres de determinada idade e localização e as suas predileções à determinado estilo literário - os quais podem ser facilmente obtidos por meio dos dados inseridos e coletados pela Rede - permitem a visualização pelo mercado a respeito de uma determinada demanda, a qual será direcionada o seu produto ou serviço.

\footnotetext{
32 " a economia da pós-produção em massa 'gerou uma nova mentalidade humana - a de um indivíduo autodeterminado. Essa mentalidade foi um dia exclusiva da elite: de ricos, artistas, poetas, filósofos. E se tornou a mentalidade de todos. "' KEEN, Andrew. Vertigem Digital: Por que as redes sociais estão nos dividindo, diminuindo e desorientando. Edição Kindle. Tradução Alexandre Martins. Editora Zahar, 2012. cap. 5, posição 1977.

${ }^{33}$ BENKLER, Yochai. The Wealth of Networks: How Social Production Transforms Markets and Freedom. Yale University Press, 2006. p. 31.
} 
Esse recurso, por si só, já constitui um bem de elevado valor monetário vez que a utilização da informação exprimida pelos dados auxilia na intervenção dos meios de produção e distribuição de outros bens econômicos. ${ }^{34}$

Assim é que na sociedade informacional - derivada da economia da informação - a produção de mercadorias e o oferecimento de serviços advêm quase que majoritariamente da coleta e análise de dados obtidos pela Rede.

Dessa forma, a Rede com sua capacidade de coletar dados de forma exponencial deu início à uma nova revolução industrial, com o surgimento de um quarto setor informacional em um ambiente que era anteriormente marcado pelos setores da agropecuária, indústria e serviços.

Assim, a economia informacional é justamente a valorização e a monetização dos dados captados - conglomerado de dados que dão forma ao fenômeno da Big Data - de forma a exprimir informações sobre as expressões da atividade humana.

Castells assevera de forma contundente que o conhecimento sempre foi de extrema valia para o mercado. Entretanto foi a partir da década de 90 que os dados passaram a constituir o próprio produto do processo produtivo, já que agem e refletem sobre todos os domínios da atividade humana, decorrendo daí a sua significância para o setor privado e público, como será melhor abordado no final deste capítulo.

A "Big Data" hoje tem como principal finalidade a obtenção de insights que levam a melhores decisões e direções estratégicas de negócio, tornado as informações extraídas do "Big Data" um bem valiosíssimo na atual estrutura de mercado, denominada por muitos como economia da informação ou economia informacional.

\footnotetext{
${ }^{34}$ WACHOWICZ, Marcos. Os impactos das novas tecnologias da informação. Revista do Direito, Santa Cruz do Sul, p. 54-89, jul. 2007. Disponível em: <https://online.unisc.br/seer/index.php/direito/article/view/182/141>. Acesso em: 02 de Maio de 2018.
} 
Assim é que a economia informacional se estruturou tendo em vista o crescente valor econômico que os dados pessoais ${ }^{35}$ apresentam para o setor privado - e também para os Governos - devido à capacidade de coleta, organização, catalogação e armazenamento desses dados. ${ }^{36}$

Um exemplo da capacidade de monetização dos dados são os reiterados escândalos que cada vez mais vem à tona a respeito do vazamento ou, em alguns casos, a própria venda de dados sem consentimento dos consumidores, que diversas sociedades empresárias vêm praticando ou sofrendo.

Um caso recente de venda de dados sem o consentimento de seus consumidores é o da startup Strava, conhecida como a "rede social dos atletas" por monitorar dados de corridas e pedaladas mundo afora. A plataforma agrupou três bilhões de pontos de GPS que, somados, cobriam 5\% da superfície terrestre.

Dois meses depois, analistas de segurança denunciaram que, acidentalmente, o mapeamento fez mais do que apenas conectar entusiastas do estilo de vida fitness. Ao mostrar dados rastreados de todos os usuários, o mapa ficou muito "iluminado" em regiões como os Estados Unidos e a Europa. Ao mesmo tempo, em locais onde a utilização era menor, como no Oriente Médio, analistas apontaram que o Strava entregou informações de militares usuários da plataforma lotados em bases secretas e suas rotinas de patrulha. ${ }^{37}$

Pode-se citar também a mais recente polêmica envolvendo a rede social Facebook, que está sendo acusada de revelar os dados de mais de 50 milhões de

\footnotetext{
${ }^{35}$ A definição de dados pessoais é dada pelo art. $2^{\circ}$ da Diretiva 95/46/EC, que afirma ser um dado pessoal qualquer informação relativa a uma pessoa natural identificada ou identificável. " $<<$ Dados pessoais $>>$ qualquer informação relativa a uma pessoa singular identificada ou identificável (pessoas em causa); é considerado identificável todo aquele que possa ser identificado, direta ou indiretamente, nomeadamente por referencia a um número de identificação ou a um ou mais elementos específicos da sua identidade física, fisiológica, psíquica, econômica, cultural ou social". Definição semelhante se encontra na legislação pátria, com o Decreto no 8.771 de 2016, em seu art. 14, inciso I.

${ }^{36}$ MORAIS, José Luis Bolzan de; NETO, Jacob de Menezes. A insuficiência do Marco Civil da Internet na proteção das comunicações privadas armazenadas e do fluxo de dados a partir do paradigma da Surveillance. In: LEITE, George Salomão; LEMOS, Ronaldo. (Org.) Marco Civil da Internet. São Paulo: Atlas, 2014. p. 418.

37 PÁDUA, Luciano. Sorria? Seus dados estão sendo compartilhados. Disponível em: $<$ https://www.jota.info/coberturas-especiais/liberdade-de-expressao/sorria-dados-compartilhados29032018>. Acesso em 04 abril de 2018.
} 
pessoas, dados esses coletados por meio do aplicativo. O caso se tornou ainda mais grave quando se tomou o conhecimento de que tais dados teriam sido utilizados pela empresa Cambridge Analytica com o intuito de fazer propaganda política nas eleições presidenciais dos Estados Unidos, em $2016 .{ }^{38}$

Importante esclarecer que apenas a coleta de dados, por si só, em tese, não representa uma ameaça à privacidade. A coleta de dados passa a ter relevância no momento em que os dados, uma vez reunidos, passam a ser organizados de acordo com uma classificação qualquer e depois armazenados.

Tal processo, denominado tratamento de $\operatorname{dados}^{39}$ é o que possibilita o mais variado conhecimento a respeito dos indivíduos ${ }^{40}$, se extraindo informações relevantes e, muitas vezes sensíveis a seu respeito.

De todo modo, Jack Balkin afirma que Big Data é um insumo essencial para a "sociedade algorítmica" - termo usado para também se referir à sociedade digital - baseada por decisões algorítmicas, que precisam ser alimentadas por dados.

Assim, a coleta de dados, o seu tratamento e o posterior armazenamento ocorrem para que os algoritmos sejam capazes de prever comportamentos e

38 COSTA, Camilla. Como descobrir o que o Facebook sabe sobre você. Disponível em <http://www.bbc.com/portuguese/geral-43493673>. Acesso em 04 de abril de 2018.

${ }^{39}$ A definição de tratamento de dados está também está prevista no art. 14, inciso II do Decreto $\mathrm{n}^{\circ}$ 8.771/2016, sendo tal processo "toda operação realizada com dados pessoais, como as que se referem a coleta, produção, recepção, classificação, utilização, acesso, reprodução, transmissão, distribuição, processamento, arquivamento, armazenamento, eliminação, avaliação ou controle da informação, modificação, comunicação, transferência, difusão ou extração". Ainda a respeito de tratamento de dados, Pierre Lévy afirma que o tratamento de dados é realizado por meio de grandes processadores que realizam cálculos aritméticos e lógicos sobre os dados produzidos. Esses cálculos são executados em grande velocidade e de forma extremamente repetitiva sobre informações codificadas digitalmente. LÉVY, Pierre. Cibercultura. Tradução de Carlos Irineu da Costa. $3^{\text {a }}$ ed. São Paulo: Editora 34, 2010. p. 33.

40 “A quantidade de informações digitais é inesgotável: toda interação eletrônica, toda operação bancária e de crédito e cada simples assinatura de uma revista ficarão digitalmente gravados e ligados a indivíduos específicos, havendo notável risco de violação do sigilo desses dados para finalidades várias, inclusive ilícitas, ainda que inúmeros usuários da rede não tenham ciência do perigoso rastro que deixam a cada acesso. Tal registro de dados fica armazenado através de cookies, que servem para guardar diversas informações sobre preferências do utente, quando foi realizado o último acesso à página que instalou o respectivo cookie, senha de acesso ao site, entre outras." LEMOS, Ronaldo. Marco Civil da Internet. São Paulo: Atlas, 2014. p. 739-740. 
muitas vezes determinar novos comportamentos, influenciando os indivíduos de acordo com o interesse do mercado.

A capacidade de influenciar comportamentos é de extrema valia para o mercado, de modo que atualmente se pode falar em monetização dos dados pessoais, ante a representatividade de seu valor econômico. A possibilidade de fiscalizar e determinar comportamentos também é um poder visado pelos Governos, motivo pelo qual o tratamento de dados também lhes é interessante.

No que tange especificamente ao interesse do mercado, é possível afirmar que a monetização dos dados coletados é a exata expressão da economia informacional.

Nesse ponto, ressalta-se que o mercado é, segundo Eros Grau, uma instituição jurídica, criada pela evolução histórica da sociedade e com o objetivo de atender aos interesses de alguns. Ainda, o mercado é entendido como uma instituição política vez que mantém certas estruturas de poder, que assegura a prevalência dos interesses de determinados grupos sociais. ${ }^{41}$

Nesse sentido, há de se notar que o atendimento aos interesses do mercado por meio da coleta e armazenamento de dados é realizada no sentido de atender os interesses de determinadas classes econômicas, as quais vislumbram a manutenção de uma estrutura de poder que lhes favoreça.

O professor Balkin ainda ressalta a incessante necessidade de angariar dados, principalmente no que tange às atividades, predileções e gostos pessoais dos indivíduos, ou de determinado grupo de pessoas. ${ }^{42}$

A possibilidade de organização desses dados, e o seu consequente armazenamento, tornou capaz a previsão de comportamentos dos indivíduos, fazendo com que as sociedades empresárias façam o uso desses dados para

\footnotetext{
${ }^{41}$ GRAU, Eros Roberto. A Ordem econômica na Constituição de 1988 (Interpretação e crítica). $14^{\mathrm{a}}$ ed. São Paulo: Malheiros Editores, 2010. p. 27-28.

${ }^{42}$ BALKIN, Jack M. Free Speech in the Algorithmic Society: Big Data, Private Governance, and New School Speech Regulation. UC Davis Law Review; Yale Law School, Public Law Research, Edição No. 615. Setembro de 2017. p.6.
} 
praticar o "web marketing" ou "marketing digital", se beneficiando das informações coletadas para anteverem e controlarem o comportamento dos consumidores da maneira que lhes seja mais favorável. ${ }^{43}$

Nesse sentido, é fácil compreender que a informação, gerada a partir da coleta de dados dos usuários da internet, o que na atualidade, significa a coleta de dados da sociedade como um todo, deu espaço a uma nova forma de riqueza, e consequentemente, de sujeitos de poder. ${ }^{44}$

\subsection{Vigilância digital}

Diante do evidente interesse do mercado e do Estado em absorver dados dos indivíduos, é de se questionar como esses dados vêm sendo coletados.

Sobre esse ponto cumpre ressaltar que os dados vêm sendo, voluntariamente, - ou melhor, ignorantemente - fornecidos pelos próprios usuários da rede $\mathrm{e}^{45}$.

Os usuários, na maioria das vezes, desconhecem o fato de que seus dados estão sendo "pescados" e, ainda que saibam que a coleta está se operando, desconhecem a finalidade que lhes será atribuída.

Desse modo é que a falta de conhecimento a respeito da coleta de dados pode representar uma afronta ao direito à privacidade no sentido que, além de

\footnotetext{
43 "O Google funciona para nós porque parece ler nossas mentes - e, de certa forma, faz. Ele adivinha o que você pode querer ver com base em pedidos que você e outros como você tenham já expressou. Você pode digitar um termo vago na consulta de pesquisa caixa, sem saber exatamente como frasear o seu desejo, e o Google irá provavelmente retornar uma lista notavelmente apropriada de coisas que você pode querer." VAIDHYANATHAN, Siva. The Googlization of Everything (and why we should worry). California: California Press, 2011. p. 52. Tradução livre.

${ }^{44}$ BALKIN, Jack M. Free Speech in the Algorithmic Society: Big Data, Private Governance, and New School Speech Regulation. UC Davis Law Review; Yale Law School, Public Law Research, Edição No. 615. Setembro de 2017. p. 6.

${ }^{45}$ ALLEN, Anita L. Protecting One's Own Privacy in a Big Data Economy. Law, Privacy \& Technology Commentary Series. Harvard Law Review. Vol. 130, No. 2, Dec. 2016. Disponível em $<$ https://harvardlawreview.org/2016/12/protecting-ones-own-privacy-in-a-big-data-economy>. Acesso em 20 de maio de 2018.
} 
possibilitar o "profiling" ${ }^{46}{ }^{47}$ dos indivíduos, isto é, a classificação dos dados e a criação de perfis que geram proveito econômico sem a devida e consciente autorização dos indivíduos; a coleta de dados contribui ainda para uma nova e temerosa forma de surveillance, ou "vigilância digital".

A vigilância digital é proveniente da sociedade em rede e da economia informacional no sentido em que a incessante busca por dados e o seu armazenamento pode constituir - e muitas vezes constitui - uma intromissão dos governos e de corporações na esfera privada dos indivíduos. ${ }^{48}$

A vigilância não é algo novo, estando já presente há muitos séculos, tendo sido primeira estudada por Michel Foucault em sua obra "Vigiar e punir" e por Jeremy Bentham em "O Panóptico". No entanto, a nova modalidade de vigilância aqui abordada, a vigilância digital, se diferencia no sentido em que a vigilância assume novas formas e proporções, se intensificando e com isso, representando cada vez mais uma ameaça a direitos fundamentais, como o direito à privacidade.

Isso ocorre tendo em vista que a vigilância passa a ser arbitrária, sistemática, metódica e de mais fácil acesso, vez que o monitoramento das ações de indivíduos ou mesmo instituições, são hoje rastreáveis pela Rede e pelas informações nela inseridas.

A vigilância digital foi deflagrada inicialmente como um meio de identificar e solucionar problemas por meio da coleta, armazenamento e análise dos dados, fazendo - se o uso da Rede como um meio de facilitação de recepção de informações, as quais auxiliam os Governos na execução de algumas de suas

\footnotetext{
46 TENE, Omar; POLONETSKY, Jules. Privacy in the Age of Big Data: A Time for Big Decisions. Stanford Law Review, 64 Stan. L. Rev. Online 63. Fevereiro de 2012. Disponível em: <https://www.stanfordlawreview.org/online/privacy-paradox-privacy-and-big-data/>. Acesso em $28 \mathrm{de}$ maio de 2018.

${ }^{47}$ DONEDA, Danilo. Da Privacidade à Proteção de Dados Pessoais. Rio de Janeiro: Renovar, 2006. p. 173.

${ }^{48}$ MOLINARO, Carlos Alberto; SARLET, Ingo Wolfgang. Breves notas acerca das relações entre Sociedade em Rede, a Internet e o assim chamado Estado de Vigilância. In: LEITE, George Salomão; LEMOS, Ronaldo (Org.). Marco Civil da Internet. São Paulo: Editora Atlas, 2014. p. 30.
} 
funções. Tal fato se justificou sob um argumento de segurança pública e de prevenção contra o terrorismo.

Ocorre que, esse aumento desenfreado da vigilância por meio da Rede justificado com base na segurança pública não deve motivar a violação de direitos fundamentais. $\mathrm{O}$ que se observa na realidade é o aproveitamento da facilidade na coleta e acúmulo de dados pela Rede para direcionar comportamentos, no caso dos Governos; assim como alimentar o novo modelo de negócios instituído pelas instituições privadas. ${ }^{49}$

\footnotetext{
${ }^{49}$ LONGHI, João Victor Rozatti. Marco Civil da Internet no Brasil: Breves considerações sobre seus fundamentos, princípios e análise crítica do regime de responsabilidade civil dos provedores. In: MARTINS, Guilherme Magalhães. (Org.). Direito privado e Internet. São Paulo: Editora Atlas, 2014. p. 113 .
} 


\title{
2. Privacidade
}

\author{
"If you want to keep a secret, \\ you must also hide it from \\ yourself." \\ - George Orwell, 1984
}

\subsection{Construção histórica do termo privacidade}

\section{Para se compreender a questão existente entre o direito à privacidade e a mais} recente modalidade de sua violação, por meio da prática de coleta e tratamento de dados pelos provedores de internet $^{50}$, é necessário estabelecer, de antemão, uma definição do instituto da privacidade no ordenamento jurídico pátrio. Feito isso, será possível adentrar a questão principal do presente estudo, qual seja, a de relacionar de que maneira a coleta e tratamento de informações fornecidas

\footnotetext{
${ }^{50}$ A respeito dos provedores de internet, Guilherme Magalhães Martins afirma que provedores devem ser classificados em cinco categorias, de acordo com as principais funções e atividades desenvolvidas: provedores de backbone, que são os responsáveis por oferecer conectividade, vendendo acesso à sua infraestrutura à outras empresas que repassam o acesso ao usuário final; provedores de conteúdo ou informação, que coletam, mantém e organizam informações online para acesso oneroso ou gratuito por meio de uma conexão com a internet; provedores de acesso, que realizam a função de do usuário com a internet; provedores de hospedagem, que se destinam a dar suporte armazenamento às páginas e sites, oferecendo um espaço de armazenamento de arquivos para os provedores de conteúdo; e, por fim, os provedores de correio eletrônico, que são os responsáveis pela troca de mensagens entre seus usuários. MARTINS, Guilherme Magalhães. Responsabilidade civil por acidente de consumo na internet. São Paulo: Editora Revista dos Tribunais, 2014. p. 335-344. Quanto à classificação apresentada por Martins, cumpre mencionar que o Marco Civil da Internet, Lei 12.965/2014, não faz a mesma distinção, tratando apenas de dois tipos de provedores. "A Lei no 12.965/2014 trata em especial de dois tipos de provedores: aqueles dedicados a prover o acesso à Internet e aqueles que disponibilizam as mais diversas aplicações na rede. Nesse sentido, o artigo $5^{\circ}$ assim define as atividades desempenhadas por esses provedores: Art. $5^{\circ}$ Para os efeitos desta Lei, considera-se: V - conexão à Internet: a habilitação de um terminal para envio e recebimento de pacotes de dados pela Internet, mediante a atribuição ou autenticação de um endereço IP; (...)VII - aplicações de Internet: o conjunto de funcionalidades que podem ser acessadas por meio de um terminal conectado à Internet." SOUZA, Carlos Affonso; LEMOS, Ronaldo. Marco Civil da Internet: Construção e Aplicação. Juiz de Fora: Editar Editora Associada Ltda, 2016. p. 68-69.
} 
pelos usuários de redes sociais e demais provedores de internet podem configurar uma violação da privacidade perante a coletividade.

Como será melhor abordado adiante, a violação à privacidade aqui tratada transmutou-se de um interesse meramente individual para o patamar de interesse coletivo, vez que não concerne mais a esfera de um indivíduo isolado, mas sim do sujeito inserido na coletividade. Nesse sentido, o direito à privacidade assume hoje uma dimensão coletiva, vez que a sua violação se dá de forma transindividual, perante a sociedade como um todo. ${ }^{51}$

Como definir um conceito tão abrangente e tão corriqueiramente invocado como o do direito à privacidade? Primeiramente, é necessário fazer uma contextualização histórica da construção desse conceito.

$\mathrm{O}$ reconhecimento do direito à privacidade, direito esse englobado pelo gênero dos valores da personalidade, ${ }^{52}$ se relaciona diretamente com a idealização da liberdade individual e o reconhecimento da autonomia privada para além das relações negociais e patrimoniais.

Surgida no século XIX, a concepção de autonomia privada foi essencial para o advento da noção de privacidade. Isso porque foi com o desenvolvimento do conceito de autonomia privada que se pôde expressar e reconhecer a liberdade individual. ${ }^{53}$

\footnotetext{
${ }^{51}$ RODOTÀ, Stefano. A vida na sociedade de vigilância: a privacidade hoje. Rio de Janeiro: Renovar, 2008. p. 21.

${ }^{52}$ Existe uma grande discussão doutrinária a respeito do que constituiriam de fato os direitos da personalidade. Contudo, de uma maneira geral, pode-se afirmar que os direitos da personalidade têm por finalidade a proteção dos direitos indispensáveis à dignidade e integridade da pessoa. De acordo com Pontes de Miranda "o direito de personalidade, os direitos, as pretensões e ações que dele se irradiam são irrenunciáveis, inalienáveis, irrestringíveis. São direitos irradiados dele os de vida, liberdade, saúde (integridade fisica e psíquica), honra, igualdade". MIRANDA, Francisco Cavalcanti Pontes de. Tratado de direito privado. Tomo I. $2^{\mathrm{a}}$. ed. Campinas: Bookseller, 2000. Carlos Alberto Bittar também define os direitos da personalidade como "são da personalidade os direitos reconhecidos à pessoa humana tomada em si mesma e em suas projeções na sociedade, previstos no ordenamento jurídico, exatamente para a defesa de valores inatos ao homem, como a vida, a higidez física, a intimidade, a honra, a intelectualidade e outros". BITTAR, Carlos Alberto. Os direitos da personalidade. $2^{\mathrm{a}}$. ed. rev. e atual. Rio de Janeiro: Forense, 1999. p. 1.

53 "Apesar de tratar-se de um quadro ideal, com uma quase ausência de plena realização histórica, ele exerceu importante influência no pensamento jurídico e na praxe, colocando-se como marca da liberdade individual." PERLINGIERI, Pietro. Perfis do Direito Civil Introdução ao Direito Civil Constitucional. Trad. Maria Cristina de Cicco. 2a . ed. Rio de Janeiro: Renovar, 2008. p. 17.
} 
A autonomia privada surgiu do reconhecimento pelo direito de que os indivíduos possuíam liberdade para regular as suas próprias manifestações de vontade, podendo determinar também as consequências jurídicas dos comportamentos adotados. ${ }^{54}$

Pode-se dizer que em um primeiro momento, a autonomia privada traduzia uma ideia meramente patrimonial e mercantilista, vez que foi pensada em um cenário de impulsionamento do liberalismo econômico e da imposição da força mercantil ${ }^{55}$. Contudo, aos poucos foi se reconhecendo a sua aplicação em relações subjetivas, de natureza pessoal e existencial, e as quais devem sempre observar o valor da pessoa.

Sob a perspectiva do reconhecimento da autonomia privada e, consequentemente, da liberdade individual dos indivíduos em poder determinar as suas relações jurídicas, é que se caminhou para o conceito e a reclamação da sociedade por um direito à privacidade, direito esse que é considerado como sendo um feixe da liberdade individual.

O termo privacidade foi primeiro empregado pelos advogados Samuel D. Warren e Louis Brandeis, que cunharam o termo "privacidade" como o "direito de ser deixado só". Tal definição foi usada no artigo escrito por ambos e intitulado "The Right To Privacy" (O Direito a Privacidade), artigo esse publicado na Harvard Law Review em Dezembro de $1890 .{ }^{56}$

O referido artigo foi publicado após uma reflexão e insatisfação dos autores diante das reiteradas invasões da privacidade social à época, principalmente no que se referia às publicações jornalísticas.

\footnotetext{
${ }^{54}$ PERLINGIERI, Pietro. O Direito Civil na Legalidade Constitucional. Trad. Maria Cristina de Cicco. Rio de Janeiro: Renovar, 2008. p. 20.

${ }^{55}$ PERLINGIERI, Pietro. Perfis do Direito Civil Constitucional . Trad. Maria Cristina de Cicco. $2^{\mathrm{a}}$ ed. Rio de Janeiro: Renovar, 2008. p. 17.

${ }^{56}$ WARREN, Samuel D.; BRANDEIS, Louis D. The Right to Privacy. Harvard Law Review, vol. 4, no. 5, 1890, p. 193-220. JSTOR, Disponível em: 〈www.jstor.org/stable/1321160〉. Acesso em 13 de Outubro de 2017.
} 
A respeito das publicações, afirmavam os autores que estas apresentavam cada vez mais um cunho imoral e isento de decência, visto que configuravam uma verdadeira "intromissão na vida doméstica dos indivíduos, o que não podia ser tolerado". ${ }^{57}$

O apelo de Warren e Brandeis teve como motivação principal a publicação pelo jornal Washington Post de uma foto do casamento da filha de Warren. Os juristas americanos também se basearam em um caso de grande repercussão na coroa britânica ocorrido em 1848.

No caso inglês, a rainha Vitória e o príncipe Albert tiveram imagens suas indevidamente disseminadas na mídia quando um funcionário de uma empresa de gravuras em placas de cobre se apropriou indevidamente de imagens pessoais do casal e de seus filhos. A questão foi levada ao judiciário, tendo o direito inglês criado um precedente no sentido de reconhecer a violação à privacidade da coroa, visto que as gravuras foram requeridas para uso pessoal, como uma forma de recordação dos sujeitos ali envolvidos. ${ }^{58}$

Foi a partir desses casos que se viu como sendo necessária a tutela do Estado na proteção da vida privada dos sujeitos, a fim de resguardar que aspectos referentes à esfera privada dos indivíduos, como o direito à imagem, por exemplo, não fossem difundidos ao público indevidamente.

O desejo de impedir a interferência na vida privada dos indivíduos surgiu no século XVIII e se desenvolveu a partir da ideia da proteção aos interesses e liberdades individuais, de pensamento, reconhecendo-se mais direitos a serem tutelados para além dos direitos tradicionalmente reconhecidos, como os direitos à propriedade, segurança e integridade física.

\footnotetext{
57 "Fotografias instantâneas e empresas jornalísticas invadiram os recintos sagrados da vida privada e doméstica; e numerosos dispositivos mecânicos ameaçam fazer bem a previsão de que "o que é sussurrado no armário deve ser proclamado dos topos das casas." WARREN, Samuel D.; BrANDEIS, Louis D.. The Right to Privacy. Harvard Law Review, vol. 4, no. 5, 1890, pp 195. JSTOR, Disponível em: <www.jstor.org/stable/1321160>. Acesso em 13 de Outubro de 2017. Tradução livre.

${ }^{58}$ KEEN, Andrew. Vertigem Digital: Por que as redes sociais estão nos dividindo, diminuindo e desorientando. Edição Kindle. Tradução Alexandre Martins. Editora Zahar, 2012. cap. 8, pos. 2846.
} 
Como bem colocou o jurista Stefano Rodotà, tal mudança se iniciou com o "desenvolvimento do sentido de intimidade". Foi com o fim da era medieval que a sociedade passou a ter uma noção e desejo de privacidade e intimidade, alterando os seus hábitos no sentido de separação entre as atividades em comum e as atividades privadas ${ }^{59}$.

O interesse e a preocupação com a privacidade e a divisão entre aquilo que devia ser público e o que devia ser reservado ao particular, dessa forma, foi decorrente de um movimento de separação dos $\operatorname{corpos}^{60}$. Tal movimento se desenvolveu fundado em um novo interesse pelo corpo humano dos indivíduos, no sentido de separá-lo da coletividade ante a compreensão da autonomia individual de cada um sobre si mesmo.

Assim, os indivíduos que na idade média estavam acostumados a viver as suas vidas abertamente de forma pública e coletiva, sem o entendimento acerca da sua individualidade, uma vez reconhecida, passaram a sentir a necessidade de se tornarem fechados em si mesmos, vivendo-se cada vez menos em coletivo $^{61}$. Desse modo, se passou ao entendimento de que certas experiências e condutas deveriam ser vividas de forma privada, não mais em frente ao público.

Lynn Hunt trata desse fenômeno da separação dos corpos para abordar a questão do reconhecimento dos direitos humanos e a tortura, que não é objeto do presente estudo, contudo serve para a reflexão acerca do início da construção da privacidade na sociedade.

No capítulo segundo de seu livro "A Invenção dos Direitos Humanos: Uma História”, Hunt ressalta que foi a partir do séc. XVIII que os indivíduos viram a necessidade de se distanciarem uns dos outros, criando espaços privados em suas próprias casas, tendo em vista o crescimento da necessidade de privacidade:

\footnotetext{
${ }^{59}$ RODOTÀ, Stefano. A vida na sociedade de vigilância: a privacidade hoje. Rio de Janeiro: Renovar, 2008. p. 20.

${ }^{60}$ HUNT, Lynn. A invenção dos direitos humanos: uma história. Trad. Rosaura Eichenberg. São Paulo: Companhia das Letras, 2009. p. 82.

${ }^{61}$ DONEDA, Danilo Da privacidade à proteção de dados pessoais. Rio de Janeiro: Renovar, 2006. p. 77.
} 
"A arquitetura residencial reforçava esse sentido de separação do indivíduo. A "câmara" (chambre) nas casas francesas tornou-se cada vez mais especializada na segunda metade do século XVIII. A sala, antes de finalidade geral, transformou-se no "quarto de dormir", e nas famílias mais ricas as crianças tinham quartos de dormir separados do de seus pais. Dois terços das casas parisienses tinham quartos de dormir na segunda metade do século XVIII, enquanto apenas uma em sete tinha salas destinadas às refeições. A elite da sociedade parisiense começou a insistir numa variedade de quartos para uso privado, que iam desde os boudoirs (que vem do francês bouâer para "amuar-se" - um quarto para expressar seu mau humor em privado) à toalete e aos quartos de banho. Ainda assim, o movimento em direção à privacidade individual não deve ser exagerado, ao menos na França."

Dessa maneira, se iniciou um movimento que favoreceu uma alteração social de comportamento da sociedade em coletivo para o indivíduo fechado em si mesmo. O indivíduo passou a demandar um espaço privado, o qual não seria submetido às interferências externas.

Com o reconhecimento desse espaço privado é que se suscitou a importância das emoções, sentimentos e relações de cada indivíduo, sendo todos esses aspectos formadores da pessoa. Essa alteração social se coaduna com o "direito de ser deixado só" posteriormente utilizado por Warren e Brandeis em 1890.

O discurso utilizado por Warren e Brandeis representou uma verdadeira declaração de reconhecimento do direito à vida privada e, em última instância, um pedido para que o ordenamento jurídico americano reconhecesse um novo direito.

Tal fato se fundamenta no fenômeno da subjetivação do direito, tendo a sociedade, após vivenciar um processo de evolução dos direitos que veio a ser mais explicitada no Iluminismo, demandado a proteção de diferentes aspectos formadores da pessoa que, em conjunto formam o direito geral de personalidade. $^{63}$

\footnotetext{
${ }^{62}$ HUNT, Lynn. A invenção dos direitos humanos: uma história. trad. Rosaura Eichenberg. São Paulo: Companhia das Letras, 2009. p. 82-85.

63 "Não admira assim, face a esse mundo em ebulição, que o homem europeu contemporâneo, causticado pela guerra e pelas crises econômicas, passe antiteticamente a reivindicar para si um certo espaço, um determinado 'território', uma concreta esfera de resguardo e de ação, que lhe possibilitem defender-se e afirmar-se no meio social. E, mais do que isso, o homem contemporâneo, embora reconheça a necessidade de igualação num conjunto de condições sociais básicas (v.g. na educação e na saúde) passa
} 
A subjetivação dos direitos se deu no sentido em que não era mais suficiente a ideia de proteção apenas dos aspectos físicos como a proteção do corpo e a propriedade, reconhecendo-se a existência de aspectos psicológicos e morais como de consciência, sentimentos, emoções e relações externas do indivíduo com a comunidade. ${ }^{64}$

Nesse sentido, restou evidenciada uma ânsia pelo também reconhecimento de um novo direito inerente aos indivíduos, sendo esse novo direito o "direito de ser deixado só".

O "direito de ser deixado só" compreende, portanto, o direito individual que deverá ser assegurado a cada um para impedir a violação pelos demais indivíduos, e aqui se inclui o Estado, da sua esfera privada, impossibilitando a divulgação e a exposição de fatos que concernem exclusivamente o indivíduo.

O conceito de privacidade como o "direito de ser deixado só", posto como foi, demonstrou a característica de individualidade que o termo continha. A privacidade era vista como um direito estritamente individual, de interesse de cada particular, se enquadrando exatamente na tendência individualista à época, que passou a reconhecer uma série de liberdades individuais, tais como o direito à vida privada.

No entanto, nota-se que tal reconhecimento do direito à privacidade e da proteção dos espaços privados, dizia respeito quase que exclusivamente às elites, que se apropriavam do espaço da esfera privada, espaço esse de usufruto exclusivo do indivíduo.

As classes menos favorecidas não eram contempladas com um "direito à uma vida privada" já que não tinham meios para se recolher a sua individualidade, o

\footnotetext{
a reclamar, ciente da sua individualidade constantemente ameaçada pela "normalização' e pela massificação, um direito à diferença que contemplem especificidade da sua personalidade." SOUSA, Rabindranath Capelo de. $O$ direito geral da Personalidade. $1^{a}$ ed. (Reimpressão) Coimbra: Coimbra Editora, 2011. p. 84.

${ }^{64}$ SOUSA, Rabindranath Capelo de. O direito geral da Personalidade. $1^{\text {a }}$ ed. (Reimpressão) Coimbra: Coimbra Editora, 2011. p. 91.
} 
que demonstrava, portanto, o caráter inerentemente burguês da privacidade, isto é, um direito criado pelas elites francesa e inglesa e direcionado para esse grupo. Somente às elites é que era reconhecido o direito à uma individualidade nascida da esfera privada. Assim, o surgimento do direito à privacidade representou, nesse sentido, a identidade da burguesia dentro do corpo social, caracterizando-se como um privilégio, uma exclusividade.

Dessa forma, é possível verificar que a privacidade não foi primeiramente concebida como sendo verdadeiramente um direito fundamental e universal, no sentido de assegurar a mesma proteção e aplicação a qual era reconhecida ao direito à integridade física do corpo, que era pacificamente reconhecida a todos os grupos sociais.

Tal distinção no reconhecimento e garantia do direito à privacidade com relação às diferentes classes sociais é explicado pelo que Bobbio, em sua obra "A Era dos Direitos", denominou de especificação dos sujeitos titulares de direitos. ${ }^{65}$ A especificação dos sujeitos titulares de direitos se dá no sentido em que os direitos declarados eram determinados em relação à apenas certo grupo de sujeitos específicos, dotados de atributos e características específicas, as quais lhes garantiam o acesso e proteção desses direitos.

Desse modo, o direito à privacidade se coadunava mais como uma prerrogativa ou um privilégio das mais altas famílias das sociedades europeias em não ter suas relações e sentimentos expostos, o que lhes conferia um espaço

\footnotetext{
65 “Além de processos de conversão em direito positivo, de generalização e de internacionalização, aos quais me referi no início, manifestou-se nestes últimos anos uma nova linha de tendência, que se pode chamar de especificação; ela consiste na passagem gradual, porém cada vez mais acentuada, para uma ulterior determinação dos sujeitos titulares de direitos. Ocorreu, com relação aos sujeitos, o que desde o início ocorrera com relação à ideia abstrata de liberdade, que se foi progressivamente determinando em liberdades singulares e concretas (de consciência, de opinião, de imprensa, de reunião, de associação), numa progressão ininterrupta que prossegue até hoje: basta pensar na tutela da própria imagem diante da invasão dos meios de reprodução e difusão de coisas do mundo exterior, ou na tutela da privacidade diante do aumento da capacidade dos poderes públicos de memorizar nos próprios arquivos os dados privados da vida e cada pessoa. Assim, com relação ao abstrato sujeito "homem", que já encontrara uma primeira especificação no "cidadão" (no sentido de que podiam ser atribuídos ao cidadão novos direitos com relação ao homem em geral), fez-se valer a exigência de responder com nova especificação à seguinte questão: que homem, que cidadão?" BOBBIO, Norberto. A Era dos Direitos. trad. Carlos Nelson Coutinho; apresentação de Celso Lafer. $7^{\mathrm{a}}$ reimpressão. Rio de Janeiro: Elsevier, 2004. p. 31.
} 
próprio de apropriação, se relacionando com o direito à propriedade em si, tipicamente burguês. ${ }^{66} 67$.

A aproximação com o direito de propriedade se mostra evidente no sentido em que do mesmo modo que o direito à propriedade permitia repelir o esbulho dos bens materiais, a privacidade permitia afastar a interferência alheia sobre a vida íntima de cada um. ${ }^{68}$

Assim, a noção de privacidade introduzida pelos juristas mencionados e a qual foi a principal ideia de privacidade ao longo dos séculos, XVIII, XIX e XX, revela a atribuição de um caráter individual ao direito à privacidade, criado pela burguesia, como uma prerrogativa do indivíduo concebido em si mesmo e voltado para si mesmo, possibilitando o seu reduto contra a interferência dos outros na sua esfera privada, no seu espaço privado.

\subsection{Positivação no direito}

A partir dessa definição de "direito de ser deixado só", pode-se observar que o termo privacidade era entendido como um mero instrumento para a realização da finalidade de ser deixado só.

Nesse sentido, o direito à privacidade era compreendido sob uma ótica estritamente individual, como uma prerrogativa individual de não sofrer com interferências da sociedade em sua esfera privada.

\footnotetext{
${ }^{66}$ RODOTÀ, Stefano. A vida na sociedade de vigilância: a privacidade hoje. Rio de Janeiro: Renovar, 2008. p. 20.

67 "Note-se que, nessa concepção inicial, a proteção à privacidade assumia uma conotação puramente negativa, porque, assim como a propriedade, impunha aos outros tão somente um dever geral de abstenção (não fazer). As semelhanças não param por aí: tal qual a propriedade, a privacidade era vista como uma aspiração excluída do horizonte das classes operárias e dos marginalizados. Albert Bendich chegaria a afirmar que 'pobreza e privacidade são simplesmente contraditórias'. E a privacidade acabaria identificada com um direito da 'era de ouro da burguesia', limitado às pessoas ricas e famosas, preocupadas em manter sua vida íntima a salvo da bisbilhotice alheia'." SCHREIBER, Anderson. Direitos da Personalidade. $2^{\mathrm{a}}$ ed. São Paulo: Atlas, 2013. p. 135.

${ }^{68}$ SCHREIBER, Anderson. Direitos da Personalidade. 2a ed. São Paulo: Atlas, 2013. p. 135.
} 
A Declaração Universal de Direitos Humanos da ONU, de 1948, foi o marco jurídico do reconhecimento do direito à privacidade, dispondo o art. XII da referida Declaração ${ }^{69}$ :

"Ninguém será sujeito à interferência em sua vida privada, em sua família, em seu lar ou em sua correspondência, nem a ataque à sua honra e reputação. Todo ser humano tem direito à proteção da lei contra tais interferências ou ataques."

É possível perceber que a Declaração de Direitos da ONU exprime exatamente a mesma ideia de privacidade declarada por Warren e Brandeis, a de proteção do indivíduo contra as interferências na sua vida privada, tratando o direito à privacidade como decorrente do direito natural dos seres humanos.

De todo modo, apesar da inclinação da sociedade em geral em salvaguardar e reconhecer que a vida privada merece proteção e tutela e, tendo em vista a crescente exponencial do fluxo de informações devido às inovações tecnológicas, o direito à privacidade encontrou o seu contraposto na medida em que se chocou com outros direitos fundamentais, como o direito à informação. ${ }^{70}$

O paradigma da relação entre o "indivíduo", compreendido por interesses individuais; e a "sociedade", orientada pelos interesses coletivos, começa a surgir dividindo opiniões e gerando insegurança jurídica. ${ }^{71}$

Tal conflito se manifestava e ainda se manifesta muito comumente em questões que envolvam o interesse geral da sociedade à informação em contraste com o interesse do particular em reservar informações atinentes à sua vida privada para si. ${ }^{72}$

69 A Declaração Universal de Direitos Humanos da ONU. Disponível em: <http://www.onu.org.br/img/2014/09/DUDH.pdf>. Acesso em 17 de maio de 2018.

70 “A evolução dos direitos fundamentais, logicamente, não parou nos direitos de terceira geração. A luta pela dignidade humana é constante na história da humanidade, e as normas jurídicas devem constantemente se adaptar às aspirações sociais e culturais que vão surgindo. É natural, portanto, que outros valores sejam acrescentados às declarações de direitos, bem como que os velhos direitos sejam constantemente atualizados para refletirem a mentalidade e as necessidades do presente." MARMELSTEIN, George. Curso de Direitos Fundamentais. $4^{\text {a }}$ ed. São Paulo: Atlas, 2008. p. 53-54.

${ }^{71}$ ELIAS, Norbert. A Sociedade dos Indivíduos. Rio de Janeiro: Jorge Zahar Ed. 1994. p. 25.

72 "A atual revolução da Web 3.0 também oferece profundos desafios à lei tradicional que protege a privacidade individual. O caso Ryan Giggs, por exemplo - que levou 75 mil pessoas a tuitar detalhes das 
Um exemplo disso é o caso das biografias não autorizadas, questão recentemente decidida pelo STF, tendo a referida Corte julgado em favor da liberdade de expressão e de criação intelectual, flexibilizando o direito à privacidade. ${ }^{73}$

Na maioria dos casos nos quais esses direitos entram em conflito, tal questão é resolvida com uma ponderação entre esses direitos e interesses, diante da análise do caso concreto. ${ }^{74}$

$\mathrm{O}$ direito à privacidade foi previsto expressamente no ordenamento jurídico nacional na Constituição Federal de 1988, a qual estabeleceu como direitos fundamentais e invioláveis o direito à intimidade, vida privada, honra e imagem ${ }^{75}$.

Ressalta-se que não fez o constituinte qualquer definição dos termos apresentados, não havendo até hoje uma definição concreta do que tais direitos constituiriam. ${ }^{76}$

estrepolias extraconjugais do jogador de futebol, mesmo contra uma determinação da Suprema Corte britânica proibindo comentários públicos sobre a vida privada de Giggs -, resultou no que Lionel Barber, editor do Financial Times, descreveu como 'o debate sobre a liberdade de nossa era'. Por um lado, a lei não pode punir 75 mil pessoas por tuitar sobre a vida sexual de Giggs; por outro, contudo, a mesma lei que deveria proteger os direitos individuais contra a sociedade deve oferecer alguma defesa contra a ridicularização pública numa era digital na qual qualquer um pode publicar qualquer coisa sobre qualquer outro". KEEN, Andrew. Vertigem Digital: Por que as redes sociais estão nos dividindo, diminuindo e desorientando. Edição Kindle. Tradução Alexandre Martins, Editora Zahar, 2012. cap. 8, pos. 2858 .

${ }^{73}$ Ver julgamento ADI ${ }^{\circ} 4815$.

${ }^{74}$ BARROSO, Luis Roberto. Colisão entre Liberdade de Expressão e Direitos da Personalidade. Critérios de Ponderação. Interpretação Constitucionalmente Adequada do Código Civil e da Lei de Imprensa. Revista de Direito Administrativo, Rio de Janeiro, v. 235, p. 1-36, jan. 2004. Disponível em: <http://bibliotecadigital.fgv.br/ojs/index.php/rda/article/view/45123/45026>. Acesso em: 28 Outubro de. 2017.

${ }^{75} \mathrm{Art} .5^{\circ}$ Todos são iguais perante a lei, sem distinção de qualquer natureza, garantindo-se aos brasileiros e aos estrangeiros residentes no País a inviolabilidade do direito à vida, à liberdade, à igualdade, à segurança e à propriedade, nos termos seguintes:

(...) X - são invioláveis a intimidade, a vida privada, a honra e a imagem das pessoas, assegurado o direito a indenização pelo dano material ou moral decorrente de sua violação;

XII - é inviolável o sigilo da correspondência e das comunicações telegráficas, de dados e das comunicações telefônicas, salvo, no último caso, por ordem judicial, nas hipóteses e na forma que a lei estabelecer para fins de investigação criminal ou instrução processual penal;

76 "De fato, a terminologia não é precisa. Por isso, preferimos usar a expressão direito à privacidade, num sentido genérico e amplo, de modo a abarcar todas essas manifestações da esfera íntima, privada e da personalidade, que o texto constitucional em exame consagrou". SILVA, José Afonso. Curso de Direito Constitucional Positivo. $37^{\text {a }}$ ed. São Paulo: Malheiros, 2014. p. 208. 
Em razão das experiências de ditaduras que os brasileiros vivenciaram, a Constituição da República de 1988 também deixou expressa a inviolabilidade do sigilo (de correspondência, das comunicações telegráficas, de dados e das comunicações telefônicas) e inviolabilidade da casa $^{77}$, representação do espaço privado por excelência.

No mesmo diploma legal, também se encontra expresso o direito à informação, que se justifica no interesse público, do coletivo, em ter acesso à informação $^{78}$.

Logo, é facilmente perceptível que esses direitos, todos previstos constitucionalmente e de igual hierarquia no direito brasileiro, podem, em algum momento, entrar em confronto.

Diante da ausência de definição pelo constituinte e legislador do que seria a intimidade, imagem, honra e vida privada, os referidos termos são costumeiramente usados como sinônimos uns dos outros, sendo usado privacidade e intimidade para tratar do mesmo aspecto, isto é, aquilo que o indivíduo tem direito de não expor ao público.

No entanto, cada termo pode assumir, de acordo com a subjetividade do locutor, um significado específico. Dessa forma, nem sempre o privado poderá ser usado como designando algo íntimo e vice-versa. O que se quer dizer é que o significado do discurso irá variar conforme quem o profere, possibilitando cada um dos termos aqui apresentados usos variados.

Mesmo sem fazer referência expressa ao termo "privacidade", o tal direito seria, de acordo com alguns doutrinadores, entendido como o termo genérico para designar as diversas manifestações da esfera particular do indivíduo.

\footnotetext{
${ }^{77}$ XI - a casa é asilo inviolável do indivíduo, ninguém nela podendo penetrar sem consentimento do morador, salvo em caso de flagrante delito ou desastre, ou para prestar socorro, ou, durante o dia, por determinação judicial;

${ }^{78}$ XIV - é assegurado a todos o acesso à informação e resguardado o sigilo da fonte, quando necessário ao exercício profissional;
} 
Nesse sentido, privacidade é:

"O conjunto de informação acerca do indivíduo que ele pode decidir manter sob seu exclusivo controle, ou comunicar, decidindo a quem, quando, onde e em que condições, sem isso poder ser legalmente sujeito." ${ }^{, 79}$

Sob essa definição, o direito à privacidade também expõe um caráter de escolha individual em querer revelar fatos da vida privada ou não. É, portanto, o exercício de uma liberdade da pessoa, sendo um direito inviolável e natural de não interferência na vida privada, mas se o indivíduo quiser revelar, ele está livre para fazê-lo. A privacidade, nesse sentido, é geralmente caracterizada por ser um direito natural, individual, inviolável e que exprime uma liberdade individual.

Assim, o direito à privacidade é entendido como um termo genérico para designar todos esses direitos invioláveis, tendo em vista que cada um desses termos possui o seu uso mais apropriado de acordo com o discurso e o contexto, sendo imprescindível o exercício interpretativo. ${ }^{80}$ De todo modo, o direito à privacidade positivado no ordenamento jurídico pátrio é visto como uma liberdade individual negativa de todos os sujeitos de direito, que tem a opção de resguardar para si fatos e aspectos da sua dita vida privada.

\footnotetext{
${ }^{79}$ PEREIRA, J. Matos. Direito de Informação. p. 15. In: SILVA, José Afonso da. Curso de Direito Constitucional Positivo. 37a ed. São Paulo: Malheiros, 2014. p. 208.

${ }^{80}$ Destaca-se aqui a importância da hermenêutica para a análise do termo privacidade. De acordo com Canotilho "interpretar uma norma constitucional consiste em atribuir um significado a um ou vários símbolos linguísticos escritos na constituição com o fim de se obter uma decisão de problemas práticos normativo-constitucionalmente fundada." CANOTILHO, J. J. Gomes. Direito constitucional e teoria da constituição. $5^{\text {a }}$ ed. Coimbra: Almedina, 2002. p. 1.184.
} 


\subsection{Mutação do conceito de privacidade diante da sociedade atual}

Como abordado, a ideia dominante sobre privacidade, primeiramente usada século XIX e a qual persiste até os dias atuais é a da privacidade como o "direito de ser deixado só", cuja lógica é exclusivamente individual.

Contudo, Rodotà em seu livro "A Vida na Sociedade da Vigilância", trata desse primeiro uso do termo privacidade por Warren e Brandeis como sendo incapaz de expressar a privacidade dentro das problemáticas trazidas pela sociedade atual.

Argumenta o autor que o termo privacidade hoje deve possuir um sentido positivo de possibilidade de controle pelos indivíduos acerca da disponibilização das informações a seu respeito, indo além do sentido negativo de não interferência.

Essa mudança de acepção está de acordo com as mutações que as inovações tecnológicas proporcionam à sociedade atual, com a quebra de paradigmas e conceitos, de modo que ensejam a reflexão sobre a proteção à privacidade sob uma forma coletiva.

A privacidade, portanto, deixa de possuir um caráter individualista para possuir um caráter coletivo, visto que alcançou uma nova dimensão no sentido de que a sua violação para um indivíduo na Rede, por meio da coleta e tratamento de dados, deixa de ser a violação a um direito isolado, para ser a violação de um indivíduo que se encontra inserido dentro do coletivo.

Nessa visão, Rodotà entende que diante da dimensão coletiva que o direito à privacidade adquiriu, o termo privacidade em si deve ser interpretado de uma nova maneira, para abarcar a "possibilidade que cada um tem de controlar o uso das informações que lhe dizem respeito". ${ }^{81}$

\footnotetext{
${ }^{81}$ RODOTÀ, Stefano. A vida na sociedade de vigilância: a privacidade hoje. Rio de Janeiro: Renovar, 2008. p. 22.
} 
"Talvez seja possível traçar um esquema deste processo, ressaltando que parece cada vez mais frágil a definição de "privacidade" como o "direito a ser deixado só", que decai em prol de definições cujo centro de gravidade é representado pela possibilidade de cada um controlar o uso das informações que lhe dizem respeito. Não que este último aspecto estivesse ausente das definições tradicionais: nelas, porém, ele servia muito mais para sublinhar e exaltar o ângulo individualista, apresentando a privacidade como mero instrumento para realizar a finalidade de ser deixado só; enquanto hoje chama a atenção sobretudo para a possibilidade de indivíduos e grupos controlarem o exercício dos poderes baseados na disponibilização de informações, concorrendo assim para estabelecer equilíbrios sócio-políticos mais adequados." ${ }^{82}$

A mutação do direito à privacidade de uma perspectiva individual para uma perspectiva coletiva se torna essencial para que se possa compreender o conflito existente entre a coleta em massa de informações pela internet e o direito à privacidade.

Isso porque a concepção do direito à privacidade em uma dimensão coletiva se dá no sentido de conferir aos indivíduos o poder de controlarem as informações obtidas sobre si mesmos ${ }^{83}{ }^{84}$, devendo agir em coletivo e no interesse do coletivo.

Essa mudança de concepção ocorre porque a sociedade hoje vive em um momento de inovações tecnológicas cada vez mais surpreendentes e muitas vezes ininteligíveis para os usuários, as quais possibilitam a violação à

\footnotetext{
${ }^{82}$ RODOTÀ, Stefano. A vida na sociedade de vigilância: a privacidade hoje. Rio de Janeiro: Renovar, 2008. p. 22.

83، A privacidade é um termo infeliz, porque não carrega nenhum sentido de sua própria costumização e contingência. Quando nos queixamos de violações à privacidade, o que realmente exigimos é alguma medida de controle sobre nossa reputação. Quem deveria ter o poder de coletar, referenciar, divulgar ou compartilhar informações sobre nós? Se eu optar por declarar meu status de relacionamento ou orientação sexual no Facebook, ainda posso considerar que estou preservando minha privacidade porque eu suponho que eu estou gerenciando a publicização dessa informação em um contexto no qual eu acho que eu entendo. A privacidade refere-se aos termos de controle sobre informações, não a natureza das informações que compartilhamos." VAIDHYANATHAN, Siva. The Googlization of Everything (and why we should worry). California: University, 2011. p. 93. Tradução livre.

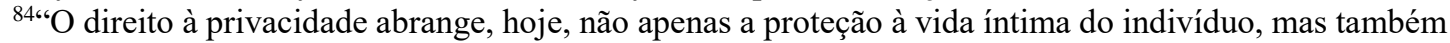
a proteção de seus dados pessoais. Em outras palavras: o direito à privacidade hoje é mais amplo que o simples direito à intimidade. Não se limita ao direito de cada um de ser 'deixado só' ou de impedir a intromissão alheia na sua vida íntima e particular. Transcende essa esfera doméstica para alcançar qualquer ambiente onde circulem dados pessoais do seu titular, aí incluídos suas características físicas, código genético, estado de saúde, crença religiosa e qualquer outra informação pertinente à pessoa. Nesse sentido, a privacidade pode ser definida sinteticamente como o direito ao controle da coleta e da utilização dos próprios dados pessoais." SCHREIBER, Anderson. Direitos da Personalidade. $2^{\mathrm{a}}$ ed. São Paulo: Atlas, 2013. p. 136-137.
} 
privacidade na maneira em que a tecnologia permite a retenção de dados dos usuários.

Tal violação se mostra cada vez mais latente se se for observar, por exemplo, as políticas e termos de uso de provedores de aplicação. Muitos deles requerem acesso e permissão para a coleta de dados e informações para muito além do que seria razoável dado a finalidade e utilidade daquele dispositivo. Assim, questiona-se a real intenção dessa coleta maciça de dados.

É fato que, as informações, de toda a natureza, constituem hoje um dos principais insumos do mercado, sendo a matéria-prima da nossa sociedade atual $^{85}$, como já fora abordado. Com isso, pode-se entender a necessidade e avidez com que as empresas coletam informações, tendo em vista o surgimento de uma nova economia baseada na informação. ${ }^{86} 87$

Entretanto, não é apenas o setor privado que valoriza a obtenção de informações. O setor público também possui grande interesse na coleta de dados visto que tal funcionalidade torna o patrulhamento exercido pelo Estado muito mais facilitado e organizado.

Michael Foucault já alertava para o mal da vigilância em 1975, quando afirmou que a vigilância constitui um instrumento para o exercício do poder disciplinar. ${ }^{88} \mathrm{O}$ poder disciplinar atua com a função de adestrar os indivíduos, ditando os comportamentos a serem seguidos não por meio da força, mas sim

\footnotetext{
${ }^{85}$ BENKLER, Yochai. The Wealth of Networks: how social production transforms market and freedom. Yale University Press, 2006. p. 30.

86“'A informação já foi referida como uma destacada 'matéria-prima' dos novos processos econômicos e sociais da Sociedade da Informação. A informação pessoal, em particular, desponta como uma verdadeira commodity em torno da qual surgem novos modelos de negócio que, de uma forma ou de outra, procuram extrair valor e utilidade do intenso fluxo de informações pessoais proporcionado pelas modernas tecnologias da informação". DONEDA, Danilo. A Proteção da Privacidade e de Dados Pessoais no Brasil. Revista Observatório Itaú Cultural. Rio de Janeiro, n. 16, 2014. p. 138

87 “A potencial ruptura com os últimos 150 anos está mascarada pelo uso liberal do termo 'economia da informação' e de suas diversas variações desde os anos 1970.o termo têm sido usado amplamente e progressivamente para significar o dramático aumento da importância da informação como meio de controle de produção e do fluxo de resultados, saídas e serviços". BENKLER, Yochai. The Wealth of Networks: how social production transforms market and freedom. Yale University Press, 2006. p. 31. Tradução livre.

${ }^{88}$ FOUCAULT, Michel. Vigiar e punir: nascimento da prisão. Trad. Raquel Ramalhete. $36^{\mathrm{a}}$ ed. Petrópolis: 2009. p. 164-170.
} 
por um meio de manobra da coletividade diante de uma multiplicidade de elementos individuais.

Assim, a vigilância de comportamentos como exercício de controle sobre os indivíduos pelo Estado se torna muito mais densificada e aperfeiçoada, se alinhando com o controle social previsto por George Orwell no sempre atual “1984".

Partindo da ideia de Foucault a respeito da vigilância, e tendo em vista a questão da privacidade ante as novas tecnologias, Lawrence Lessig vê a tecnologia como uma ferramenta poderosa para controle dos indivíduos pelo monitoramento online. ${ }^{89}$ Isso porque, para Lessig, todo e qualquer dado, não só aqueles inseridos na internet, são fatos e informações a respeito do indivíduo, formadores da pessoa.

Lessig faz uma distinção da proteção da privacidade em dois sentidos distintos. $\mathrm{O}$ primeiro deles diz respeito à privacidade no ambiente privado, isto é, ao direito de não intervenção de outros em espaços tradicionalmente privados, como a casa, por exemplo. Esse primeiro aspecto da privacidade é, portanto, “o direito de ser deixado só" idealizado por Warren e Brandeis e cuja compreensão acerca da necessidade de sua proteção se dá de forma mais pacífica. ${ }^{90}$

O segundo aspecto da privacidade é a em público, em ambientes públicos, como na rua. Isso significa que a mesmo que se esteja inserido em um ambiente público, ainda há o direito à privacidade. Em princípio, não era reconhecida essa

\footnotetext{
89 "Em ambos os casos, a internet produziu essa perda de controle: com os direitos autorais, porque essa tecnologia permite cópias de conteúdo perfeitas e gratuitas; com privacidade, como veremos nesse capítulo, porque a tecnologia permite um monitoramento de comportamento perpétuo e barato." LESSIG, Lawrence. Code Version 2.0. Nova Iorque: Basic Books, 2006. p. 200. Tradução livre.

90 “A questão tradicional da privacidade é o do limite que o direito atribuía à habilidade de outros de penetrarem em seu espaço privado. Que direito o governo tem de entrar em sua casa ou procurar seus documentos? Que proteção o direito de propriedade garante contra outros além do governo vasculhando suas coisas privadas? Esse é um dos sentidos do slogan de Brandeis do 'direito de se ser deixado só'. Da perspectiva do direito, é o conjunto de restrições legais sobre o poder dos outros de invadir um espaço protegido.” LESSIG, Lawrence. Code Version 2.0. Nova Iorque: Basic Books, 2006. p. 201. Tradução livre.
} 
segunda concepção de proteção à privacidade, já que se entendia que no espaço público, as informações tinham o aval da livre circulação.

Tal entendimento mudou, vez que a violação à privacidade em público se dá sob dois ângulos que se complementam. O primeiro é pelo monitoramento das ações do indivíduo no espaço público ("monitorable") e o segundo é pelo registro de dados obtidos por meio do monitoramento, que forma um grande acervo de dados a serem consultados pelos demais indivíduos ("searchable"). ${ }^{91}$

Dessa forma, a capacidade de retenção de dados, que hoje pode se referir à toda e qualquer informação sobre uma pessoa, contribui para um aumento do monitoramento dos indivíduos, já que os dados coletados são armazenados e podem servir para as mais diversas finalidades, de acordo com o tratamento das informações.

Dessa forma é que o autor aponta que os dados inseridos e coletados na Rede compõe um verdadeiro dossiê de cada indivíduo, que poderá ser acessado por diversos sujeitos, sem que tenha havido necessariamente o consentimento do indivíduo para o acesso de seus dados.

Assim, torna-se evidente que, para a sociedade do século XXI, informação é poder, sendo essa a principal moeda de troca na sociedade. É partir das informações coletadas que se permite a vigia dos comportamentos por diferentes sujeitos e um maior acesso aos dados de todos, sendo possível exercer controle sobre a coletividade por meio da complexidade de indivíduos.

Nesse sentido, a conveniência e os benefícios proporcionados pelas inovações tecnológicas, passam a cada vez mais significar vigilância e controle de comportamentos, algo tão contraposto com a ideia inicial de internet como liberdade.

\footnotetext{
91 "Eles não apenas fazem com que os comportamentos sejam mais monitoráveis, eles também fazem com que os comportamentos sejam mais pesquisáveis. As mesmas tecnologias que coletam dados agora também os coletam de uma forma que os tornam mais pesquisáveis”. LESSIG, Lawrence. Code Version 2.0. Nova Iorque: Basic Books, 2006. p. 200. Tradução livre.
} 


\section{Regulamentação da coleta de dados}

Diante da problemática exposta nos dois primeiros capítulos, é possível perceber que o conflito entre as novas tecnologias e a proteção do direito à privacidade se tornou uma tendência na atual sociedade.

Dito isso, é que começam a surgir propostas de regulamentação do uso das novas tecnologias no sentido de promover a proteção de dados e, por conseguinte, de proteger o direito fundamental à privacidade.

Contudo, antes mesmo de adentrar as diversas propostas de regulamentação das novas tecnologias, deve-se deixar claro que a regulamentação é necessária, sendo ela o único caminho para que a sociedade possa fazer o uso das novas tecnologias e dos meios de produção em geral sem que se instaure uma ordem de insegurança jurídica e violação de direitos fundamentais e liberdades.

O filósofo Joseph William Singer, ao abordar a questão do mercado e de regulação em sua obra "No Freedom Without Regulation" (Não há liberdade sem regulação) alerta para o fato de que a regulamentação é necessária e positiva no sentido que ela possibilita à todos o exercício do direito à liberdade e de diversos outros direitos, como o direito à propriedade ${ }^{92}$.

Citando John Locke, que afirmou "não existe liberdade sem lei"93, Singer demonstra que o dualismo existente, e cada vez mais acentuado, entre o pensamento conservador e o liberal deve ser repensado visto que ambos têm em comum os mesmos objetivos, isto é, o exercício de liberdades.

\footnotetext{
${ }^{92}$ SINGER, Joseph William. No Freedom Without Regulation: The Hidden Lesson of the Subprime Crisis. Londres: Yale University Press, 2015. p. 1-24.

${ }^{93}$ LOCKE, John. O Segundo Tratado sobre o Governo Civil. trad. Magda Lopes e Marisa Lobo da Costa. Petrópolis: Editora Vozes, 1994. Capítulo VI, parágrafo 57.
} 
A respeito do conceito de liberdade, Singer ressalta que esta não pode ser entendida como o direito de se fazer o que bem quiser, mas sim a possibilidade de exercer direitos estabelecidos por leis e cujo exercício é por elas protegido.

A liberdade como o direito de se fazer o que quiser sem o estabelecimento de quaisquer diretrizes e limites, não é liberdade já que se estará vulnerável à restrição da sua liberdade por outros, que de forma inconsequente e tirânica, podem limitar a liberdade de alguns.

Isto quer dizer que, sem lei - e lei aqui significa regulamentação - não é possível a convivência em uma sociedade que preze por valores como liberdade, igualdade e democracia. Dessa forma, para que seja possível aos indivíduos exercerem certas liberdades sem a ação predatória de alguns, a regulamentação se faz imprescindível.

Assim, se tem que a lei, a regulamentação e o governo são necessários para o estabelecimento e a manutenção de liberdades e direitos, motivo pela qual a concepção de que o governo e a regulamentação são prejudiciais à liberdade dos indivíduos é extremamente equivocada e deve ser superada.

Singer ilustra esse argumento ao afirmar que a regulação, vista por muitos conservadores como essencialmente negativa, vez que estes acreditam ser a regulamentação uma espécie de "interferência" em suas liberdades, é o que possibilita a existência de institutos por eles tão caros, como o direito de propriedade e o mercado.

O direito à propriedade é definido e estabelecido por lei, assim como o seu exercício e a sua proteção. Desse modo, sem a regulamentação, não haveria o direito à propriedade, não podendo se afirmar, portanto, que a regulamentação representa uma constrição de liberdades vez que ela, na verdade, permite exatamente o exercício pleno das liberdades.

Tal pensamento é compartilhado por Gustavo Binenbojm que, ao tratar do poder de polícia da administração pública e regulação, afirma que "o direito 
fornece à economia instrumentos jurídicos variados de garantia institucional de direitos e de indução a comportamentos, servindo como diretrizes eficientes de orientação aos agentes econômicos envolvidos em determinado mercado, para atingimento de fins legítimos estabelecidos pelo regime político."94

Sob esse entendimento é que Singer argumenta e propõe, dentro de uma abordagem econômica e de mercado, que é necessário afastar a ideia dualista entre conservadorismo e liberalismo, no qual os primeiros acreditam que toda e qualquer regulamentação é negativa, enquanto que os liberais acreditam que o Estado deve sempre atuar ativamente. Só dessa forma será possível se pensar a regulamentação como concretizadora de liberdades e como necessária ao exercício pleno de qualquer direito.

Analisando-se agora mais especificamente a regulamentação do uso da Rede e do acesso de dados nela inseridos, deve-se levar em consideração a noção de que a Rede promove e difunde um conhecimento ${ }^{95}$, conhecimento esse que assume um caráter de common, distinto da ideia tradicional de propriedade.

Rodotà aborda a transformação da concepção do direito de acesso à internet como a criação de um novo tipo de bem, dentro da ideia de bem comum, classificação essa que também se englobaria bens como a água, o ar, etc. Ele afirma que o acesso a esses bens comuns caracteriza a concretização de direitos fundamentais, já que estes contribuem para a formação do sujeito. ${ }^{96}$

Destaca-se o acesso à internet como uma nova categoria de bem comum e que atende ao interesse difuso, visto que o acesso à Rede possibilita o direito fundamental ao conhecimento e à liberdade de expressão, vez que o conhecimento - muitas vezes obtido pela Rede - é um fator determinante para a

\footnotetext{
${ }^{94}$ BINENBOJM, Gustavo. Poder de polícia, ordenação, regulação: transformações político-jurídicas, econômicas e institucionais do direito administrativo ordenador. Belo Horizonte: Fórum, 2016. p. 154. ${ }^{95}$ Conhecimento aqui disposto que remete à ideia de inteligência coletiva introduzida por Pierre Lévy, em Cibercultura. LÉVY, Pierre. Cibercultura. $3^{a}$ ed. Trad. Carlos Irineu da Costa. São Paulo: Editora 34, 2011. p. 25-27.

${ }_{96}$ RODOTÀ, Stefano. Il terribile diritto. Studi sulla proprietà privata e i beni comuni. Bologna: Il Mulino, 2013. p. 467-468.
} 
formação do indivíduo e para a formação de uma pessoa constitucionalizada, nas palavras de Rodotà. ${ }^{97}$

Rodotà, assim como Lévy ${ }^{98}$, entende que o acesso à Internet produz um conhecimento generalizado e global e que, a extensão à esse direito como um direito fundamental configuraria um espaço comunitário, que para Lévy é o ciberspaço.

$\mathrm{Na}$ construção desse pensamento, contudo, Rodotà faz uma distinção interessante a respeito do acesso à internet como um bem que não se coaduna com as características tradicionais de bens. Ele ressalta que o acesso à Internet, diferentemente de outros bens - inclusive bens que integram a categoria de bens comuns como é o caso da água - não é passível de escassez, visto que o acesso à Internet permite o uso contemporâneo e análogo do conhecimento por uma multiplicidade de sujeitos.

É sob essa perspectiva que Rodotà também defende a superação da lógica binária entre propriedade comum e propriedade privada, visto que $\mathrm{o}$ conhecimento atingido por meio do acesso à Internet se insere numa categoria nova de bem comum, e que vai de encontro à paradigmas antes existentes.

Nesse sentido, diante da constatação do acesso à Internet como um direito fundamental e da sua classificação como uma nova modalidade de bem comum que não é passível de escassez e deve ser garantida à sua fruição à todos, é que se faz necessária a regulamentação da matéria, de modo à permitir o devido acesso à Internet como abordado por Rodotà.

Para tanto, é necessário também o estabelecimento de uma autoridade garante, isto é, uma autoridade independente que possa fiscalizar e defender o acesso à Rede como mencionado por Rodotà, no sentido de garantir o acesso pleno a todos.

\footnotetext{
${ }^{97}$ RODOTÀ, Stefano. Il terribile diritto. Studi sulla proprietà privata e i beni comuni. Bologna: Il Mulino, 2013. p. 468.

${ }^{98}$ LÉVY, Pierre. Cibercultura. $3^{\mathrm{a}}$ ed. Trad. Carlos Irineu da Costa. São Paulo: Editora 34, 2011. p. 29.
} 
A importância do estabelecimento de autoridades independentes que possam tutelar o direito fundamental à privacidade ante à proliferação da prática e de instrumentos de coleta de dados é matéria abordada por Danilo Doneda que, ao analisar diversos modelos de proteção de dados pessoais no mundo, atenta para essa tendência.

Ele afirma que a criação de autoridades independentes é uma medida essencial e natural para a efetiva proteção de dados. Isso porque é necessário o estabelecimento de uma estrutura fiscalizadora, especializada na matéria e dotada de independência funcional, razão pela qual será possível realizar uma aproximação entre o Estado, o mercado e a pessoa. ${ }^{99}$

A qualidade de independência funcional dessas autoridades mostra-se imprescindível, no sentido que é necessário afastar a influência de Governos na sua atuação. Como já afirmado anteriormente no presente trabalho, Governos possuem grande interesse na coleta de dados dos indivíduos, motivo pelo qual o seu distanciamento é medida acertada.

No entanto, a instituição de uma autoridade independente também não pode significar a auto-regulamentação pelo mercado, devendo a autoridade ainda ser vinculada ao Estado, porém ser dotada de autonomia funcional. A vinculação da autoridade fiscalizadora à administração púbica, mesmo que dotada de certa independência, garante a observância de princípios e direitos fundamentais, o que para uma autoridade não estatal pode não ser uma prioridade. ${ }^{100}$

Dessa forma, faz-se necessário analisar agora as respostas legislativas escolhidas pelo direito no sentido de regulamentar tal situação.

Primeiro, se irá analisar como a proteção contra a coleta de dados foi disciplinada nos diplomas estrangeiros dentre os quais a doutrina pôde extrair alguns princípios fundamentais que irão reger a maioria dos projetos e leis

\footnotetext{
${ }^{99}$ DONEDA, Danilo. Da privacidade à proteção de dados pessoais. Rio de Janeiro: Renovar, 2006. p. 387.

${ }^{100}$ Ibid. p. 389.
} 
regulatórias quanto à questão - para, posteriormente, analisar os diplomas legais vigentes e outros ainda em andamento no Brasil.

\subsection{A regulamentação da coleta de dados nos diplomas estrangeiros}

As primeiras iniciativas legislativas versando sobre os limites a serem impostos à utilização das novas tecnologias surgiram a partir da década de 70 . Desde então, as leis sobre proteção de dados passaram por uma grande evolução, tendo o professor Viktor Mayer-Scönberger identificado quatro gerações de leis. $^{101}$

Pois bem. Apesar de desde a década de 70 já existirem leis tratando a respeito da proteção de dados, foi a partir da década de 80 que se iniciou de fato uma tradição de leis e normas mais vigorosas quanto à proteção de dados e privacidade.

A Convenção no 108 do Conselho Europeu de 1981, a chamada Convenção de Estrasburgo, foi muito positiva visto que foi a pioneira a introduzir normas

101 A respeito das gerações identificadas por Mayer-Scönberger, cumpre mencionar que a primeira geração de diplomas legais tratando sobre proteção de dados se iniciou em 1970 e se caracterizou pelo fato de que as referidas leis refletiam o estado da tecnologia e a visão dos juristas no início da evolução dos computadores. Danilo Doneda exemplifica essa primeira geração de leis com a Lei de Hesse alemã e o Privacy Act norte-americano, de 1974. Diante da falta de previsibilidade e da ausência de experiência no tratamento dessas tecnologias, essas primeiras leis possuíam um caráter de proteção mais abstrato e geral, algo que inviabilizou uma proteção de dados mais efetiva. A segunda geração se iniciou no final da década de 70, sendo essa geração caracterizada pela estruturação a partir do entendimento da privacidade como uma liberdade negativa, sem o enfoque no fenômeno computacional em si. A terceira geração se deu na década de 80 e foi marcada pela preocupação com a efetividade da proteção da privacidade e com uma participação mais ativa do indivíduo, prevendo-se, portanto, uma proteção um pouco mais robusta quanto o direito à privacidade. Já a quarta geração é a geração de leis mais atuais, nas quais se entende a proteção à privacidade não mais com um enfoque individualista, mas sim de forma coletiva, com a previsão de instrumentos que permitam uma proteção coletiva da privacidade e dos dados. Outra importante inovação vista na quarta geração de leis é a previsão de autoridades independentes que tenham como finalidade a fiscalização e a garantia da proteção de dados, levando em consideração o não equilíbrio entre o sujeito em relação às sociedades empresárias e o Estado, principais interessados na coleta de dados. DONEDA, Danilo. O Direito Fundamental à Proteção de Dados Pessoais. In: MARTINS, Guilherme Magalhães. (Org.). Direito Privado e Internet. São Paulo: Editora Atlas, 2014. p. 66-69. 
que vieram a inspirar iniciativas normativas para um modelo robusto de tutela, que hoje é referência no mundo todo. ${ }^{102}$

Dado a peculiaridade do velho continente e do seu sistema normativo, o modelo europeu de proteção de dados era composto por diretivas, regulamentos, decisões vinculantes e orientações de diversos níveis hierárquicos, com uma multiplicidade de meios regulamentadores, que partiam sempre de orientações gerais e estabeleciam normas cada vez mais específicas sobre aos limites de coleta, tratamento e armazenamento de dados.

Até maio de 2018, a Diretiva 95/46/CE era o principal texto regulamentador dentro do sistema europeu de proteção de dados. A referida Diretiva traduziu os principais conceitos no campo da proteção dos dados na União Europeia - como o conceito de dados pessoais - assim como estabeleceu uma série de princípios a serem observados sobre a matéria.

A Diretiva ainda previu certos direitos básicos dos titulares dos dados tratados, assim como estabeleceu padrões para as transferências internacionais de dados e criou ainda um aparato de supervisão. ${ }^{103}$

Além da Diretiva 95/46/CE, outras diretivas, de caráter complementar, foram também criadas, buscando a transposição dos princípios da Diretiva 95/46 para outras áreas de controle antes não abrangidas pelo sistema. Cita-se a Diretiva 2002/58/CE12, do Parlamento Europeu e do Conselho Europeu, que tratou a respeito do tratamento de dados pessoais e a proteção da privacidade no setor das comunicações eletrônicas. Essa Diretiva abordou questões mais específicas, como a guarda de dados de conexão para fins de faturamento dos serviços de conexão prestados, a utilização de dados pessoais em listagens públicas (como listas telefônicas), e a utilização dos denominados "cookies". 104

102 GUIDI, Guilherme Berti de Campos. Modelos regulatórios para proteção de dados pessoais. Disponível em: $<$ https://itsrio.org/wp-content/uploads/2017/03/Guilherme-Guidi-V-revisado.pdf . Acesso em 17 de maio de 2018. p 4.

${ }^{103}$ Ibid. p. 4.

${ }^{104}$ Cookies são arquivos de texto muito simples, cuja composição depende diretamente do conteúdo do endereço Web visitado. Por exemplo, a maioria dos sites armazenam informações básica, como 
Apesar das Diretivas acima citadas, as mesmas deixaram de ser o principal texto normativo europeu sobre proteção de dados, visto que em 25 de maio de 2018, passou a vigorar o General Data Protecting Regulation, o GDPR.

O GDPR, idealizado desde 2010 e aprovado em 2016, é o mais novo - e mais completo - regulamento sobre proteção de dados pessoais em vigor na Europa e no mundo como um todo. Com eficácia para todos os dados de cidadãos europeus, manuseados dentro ou fora da União Europeia, sua importância se dá tendo em vista ter o texto apresentado expressivas alterações em relação à Diretiva 45/96/CE.

O novo regulamento geral sobre proteção de dados se destaca pelo fato de que trouxe previsões que buscam reforçar os direitos dos usuários, as competências das autoridades de proteção de dados, assim como busca incentivar - e também desestimular, por meio de pesadas sanções, principalmente econômicas ${ }^{105}$ - certos comportamentos por parte dos responsáveis pela coleta e tratamento de dados.

Além disso, com o GDPR, as sociedades empresárias terão uma série de novas atribuições e passam a atuar de forma preventiva no assunto. Pode-se citar medidas como a obrigatoriedade de nomeação de um encarregado de proteção de dados (DPO - Data Protection Officer); a realização de auditorias internas; a elaboração de uma política de tratamento de dados pessoais; a criação de procedimentos que garantam a proteção dos dados pessoais; a elaboração de comunicados sobre privacidade; a preparação de procedimentos de resposta a

endereços IP e preferências de idioma cores e senhas. GUGIK, Gabriel. O que são cookies? Disponível em: 〈https://m.tecmundo.com.br/web/1069-o-que-sao-cookies-.htm>. Acesso em 18 de maio de 2018.

${ }^{105} \mathrm{O}$ GDPR, visando dar maior eficácia à adoção das medidas que estabelece, determinou sanções econômicas às sociedades empresárias que descumprirem com as suas normas, impondo multas que podem alcançar o patamar de $4 \%$ sobre a faturamento anual global das sociedades empresárias ou o valor de fixo de $€ 20.000 .000,00$, dependendo do qual for maior. 
solicitações dos titulares dos dados e a manutenção da documentação apropriada como evidência de todo o processo. ${ }^{106}$

Dessa forma, a nova regulamentação europeia trata-se de um produto da evolução da sociedade e do surgimento das novas tecnologias, levando em consideração a mudança do conceito de privacidade, que possui hoje uma concepção coletiva de sua tutela.

Em vista disso, a nova regulamentação traduz uma nova lógica de regulação, a qual deixa de ter como preceito do consentimento individual de cada usuário para uma concepção coletiva da privacidade. ${ }^{107}$

Cumpre mencionar também, de forma muito breve, o modelo americano de proteção de dados, o qual se distingue e muito do sistema europeu já abordado.

O modelo norte-americano de regulação é extremamente diferente do modelo europeu tendo em vista ser os Estado Unidos um país caracterizado pela adoção de um modelo federalista muito forte, com alto nível de descentralização. Devido à essa característica de descentralização é que não há nos Estados Unidos uma legislação federal específica que regulamente a a proteção de dados de forma geral. ${ }^{108}$

Apesar disso, não pode se falar que os americanos não possuem qualquer legislação sobre proteção de dados. Isso porque os Estados Unidos possuem leis federais setoriais como o Privacy Act de $1974^{109}$, Children`s Online Privacy Protection Act de $1998^{110}$ e o Health Insurance Portability and Accountability

106 LEMOALLE, Edouard; CARBONI, Guilherme. Lei Europeia de Proteção de Dados Pessoais (GDPR) e seus efeitos no Brasil. Disponível em <https://www.jota.info/opiniao-e-analise/artigos/leieuropeia-de-protecao-de-dados-pessoais>. Acesso em 19 de Maio de 2018.

107 PÁDUA, Luciano. Sorria? Seus dados estão sendo compartilhados. Disponível em: https://www.jota.info/coberturas-especiais/liberdade-de-expressao/sorria-dados-compartilhados29032018. Acesso em 19 de Maio de 2018.

108 GUIDI, Guilherme Berti de Campos. Modelos regulatórios para proteção de dados pessoais. Disponível em: <https://itsrio.org/wp-content/uploads/2017/03/Guilherme-Guidi-V-revisado.pdf>. Acesso em 17 de maio de 2018. p. 10.

${ }^{109}$ É a lei federal vigente que estabelece os princípios e regras para a coleta, armazenamento, uso e comunicação de dados pessoais nas atividades estatais conduzidas pelas agências federais.

${ }^{110}$ Cria salvaguardas para a interação de crianças com menos de 13 (treze) anos com a Internet em geral e no que diz respeito a sua privacidade. 
Act de $1996^{111}$, que atendem à necessidade de proteção de dados dentro de um setor específico.

Dessa forma, o modelo americano se caracteriza pela existência de leis setoriais no que tange à proteção de dados, e assim se difere do modelo europeu segundo o qual vigora um modelo de adoção de uma lei geral para o assunto, a ser observado por todos os setores, como ocorreu com a Diretiva 95/46/CE e, agora, com o GDPR.

A respeito do estabelecimento de autoridades fiscalizadoras para garantir a proteção de dados, se verifica que o sistema norte-americano não estabelece uma autoridade fiscalizadora específica para a proteção de dados. O que se tem são órgãos já existentes e não exclusivos do governo que atuam como agências reguladoras, sendo responsáveis pelo cumprimento das leis vigentes, igualmente separados por setores econômicos, de modo que sua atuação não é necessariamente homogênea. ${ }^{112}$

Visto estes dois modelos de proteção de dados muito distintos, passa-se agora à análise de certos princípios que geralmente se encontram presentes nos diplomas legais que versam sobre proteção de dados no mundo, e os quais deverão estar presentes em uma eventual lei de proteção de dados brasileira, se esta vier a ser promulgada.

\subsubsection{Princípios}

A partir da análise de alguns modelos de proteção de dados no plano internacional, é possível perceber que grande parte dos diplomas sobre proteção

\footnotetext{
111 Também é uma lei federal que trata da privacidade e proteção de dados médicos. A referida lei traz disposições padrões de segurança, física e técnica, para dados relacionados à saúde em formato eletrônicos; a obrigação de notificar os titulares dos dados, e muitas vezes a Secretaria de Saúde e a mídia local no caso de vazamento ou violações de dados pessoais.

${ }^{112}$ GUIDI, Guilherme Berti de Campos. Modelos regulatórios para proteção de dados pessoais. p. 13. Disponível em: <https://itsrio.org/wp-content/uploads/2017/03/Guilherme-Guidi-V-revisado.pdf>. Acesso em 17 de maio de 2018.
} 
de dados consagra alguns princípios que devem ser observados quanto à coleta, tratamento, uso e armazenamento de dados pessoais.

Tratam-se de cinco princípios que devem nortear a matéria, são eles: princípio da publicidade ou transparência, princípio da exatidão ou qualidade, princípio da finalidade, princípio do livre acesso e, por fim, princípio da segurança física e lógica dos dados. ${ }^{113}$

O primeiro princípio, o da publicidade ou transparência, determina a que o tratamento de dados pessoais não pode ser realizado sem o conhecimento do titular dos dados, que deve ser informado, especificamente sobre todas as informações relevantes concernentes a esse tratamento.

Já o princípio da qualidade ou exatidão determina que os dados armazenados devem ser fieis à realidade, atualizados, completos e relevantes, o que compreende a necessidade de que sua coleta e seu tratamento sejam feitos com cuidado e correção, e que sejam realizadas atualizações periódicas conforme a necessidade.

O terceiro princípio, o da finalidade, parece o mais caro e mais lógico de todos, pelo qual qualquer utilização dos dados pessoais deve obedecer à finalidade comunicada ao interessado antes da coleta dos mesmos.

Esse princípio possui grande relevância prática: com base nele fundamentase a restrição da transferência de dados pessoais a terceiros, prática muito comum entre as instituições privadas, que lucram demasiadamente com a coleta e transferência de dados para além da função necessária para a prestação do serviço oferecido pelo aplicativo ou site.

Assim, delimitando-se a coleta e o armazenamento de acordo com finalidade para o qual o dado será coletado, torna-se possível estruturar um critério para

\footnotetext{
${ }^{113}$ DONEDA, Danilo. O Direito Fundamental à Proteção de Dados Pessoais. In: MARTINS, Guilherme Magalhães (Org.). Direito Privado e Internet. São Paulo: Editora Atlas, 2014. p.71-72. Danilo Doneda também discorre sobre os citados princípios em sua obra "Da privacidade à proteção de dados pessoais". Rio de Janeiro: Renovar, 2006. p. 215-217.
} 
valorar a razoabilidade da utilização de determinados dados, de modo que não ocorram abusos e excessos na coleta e armazenamento.

O quarto princípio, do livre acesso, prevê que o indivíduo deve ter acesso às suas informações armazenadas em um banco de dados, podendo obter cópias desses registros; após esse acesso, e de acordo com o princípio da qualidade, as informações incorretas poderão ser corrigidas, aquelas registradas indevidamente poderão ser canceladas e aquelas obsoletas ou impertinentes poderão ser suprimidas, o mesmo pode se proceder a eventuais acréscimos.

Por fim, tem-se o princípio da segurança física e lógica, pelo qual os dados devem ser protegidos por meios técnicos e administrativos adequados contra os riscos de seu extravio, destruição, modificação, transmissão ou acesso não autorizado. Esse princípio visa exatamente estimular o investimento das sociedades empresárias contra vazamentos de dados, os quais violam obviamente o direito à privacidade daqueles que tiveram os seus dados coletados.

A observância de tais princípios no estabelecimento de regulamentações se mostra necessário para uma efetiva tutela do direito fundamental à privacidade na atual sociedade.

Isso porque o direito à privacidade de um indivíduo é afetada diretamente pelo tipo de divulgação e utilização que é feita das informações - obtidas pelos dados - registradas a seu respeito.

Dessa forma é que os dados devem ser administrado por meio de procedimentos que permitam a este indivíduo ter o direito de participar na sua decisão sobre qual deve ser o conteúdo deste registro e qual a divulgação e utilização a ser feita das informações pessoais contidas nos dados. ${ }^{114}$ Qualquer registro, divulgação e utilização das informações pessoais fora destes procedimentos não devem ser permitidas, por consistirem em uma prática

\footnotetext{
${ }^{114}$ DONEDA, Danilo. A proteção da privacidade e de dados pessoais no Brasil. Revista Observatório Itaú Cultural, 16ª ed. São Paulo: Itaú Cultural, jun/julho 2014. p. 143.
} 
desleal, a não ser que tal registro, utilização ou divulgação sejam autorizados por lei.

\subsection{A regulamentação da coleta de dados no Brasil}

Apesar de diversos países já possuírem diplomas legais e regulamentações bem robustas a respeito do uso da rede e da proteção de dados dos seus usuários, o Brasil ainda carece de uma lei específica que tutele a proteção de dados na Internet.

No entanto, o nosso ordenamento jurídico atual já possui alguns diplomas legais que são utilizados para fundamentar e reger a coleta de dados e a sua proteção, inclusive positivando alguns dos princípios acima abordados.

Como já tratado anteriormente, o direito fundamental à privacidade foi previsto expressamente no ordenamento jurídico nacional na Constituição Federal de 1988, a qual estabeleceu em seu art. $5^{\circ}$, incisos X e XII, como direitos fundamentais e invioláveis o direito à intimidade, vida privada, honra e imagem, assim como o sigilo da correspondência, de dados e das comunicações telefônicas. ${ }^{115}$

A Constituição, portanto, previu em um primeiro momento a inviolabilidade de esfera da vida privada e o sigilo das comunicações e dos dados, verificandose desde logo uma norma que afirmou a proteção à privacidade e a necessidade de resguardar à vida privada sem a que haja a intromissão de terceiros não autorizados.

\footnotetext{
${ }^{115}$ Art. $5^{\circ}$ Todos são iguais perante a lei, sem distinção de qualquer natureza, garantindo-se aos brasileiros e aos estrangeiros residentes no País a inviolabilidade do direito à vida, à liberdade, à igualdade, à segurança e à propriedade, nos termos seguintes:

(...) X - são invioláveis a intimidade, a vida privada, a honra e a imagem das pessoas, assegurado o direito a indenização pelo dano material ou moral decorrente de sua violação;

XII - é inviolável o sigilo da correspondência e das comunicações telegráficas, de dados e das comunicações telefônicas, salvo, no último caso, por ordem judicial, nas hipóteses e na forma que a lei estabelecer para fins de investigação criminal ou instrução processual penal;
} 
$\mathrm{O}$ art. $5^{\circ}$, assim, apresenta já uma norma no sentido de proteger dados, a intimidade e vida privada dos indivíduos, tutelando o direito à privacidade. Contudo, não é só a Constituição que é aplicável na tutela do direito à privacidade.

Em 2014, o Poder Legislativo brasileiro aprovou o chamado Marco Civil da Internet, Lei 12.965/2014, que veio a ser a primeira lei geral sobre Internet no Brasil, tendo estabelecido normas gerais, princípios e diretrizes a serem observadas no uso da Rede, inclusive no que toca o direito à privacidade na coleta e armazenamento de dados.

Pois bem. Apesar de estabelecer normas que demonstram a preocupação com a proteção da privacidade dos usuários na Rede, o Marco Civil não pode ser considerado como uma lei específica de proteção de dados visto que traz disposições muito abstratas e gerais quanto à proteção dos dados em si. O MCI, portanto, não definiu certos conceitos necessários para a efetiva tutela da proteção de dados, não tendo definido o conceito de dados pessoais; além de não ter estabelecido quaisquer sanções ou mesmo apontado uma autoridade fiscalizadora que possa garantir a efetiva proteção da privacidade dos usuários da Rede.

Assim é que o Marco Civil da Internet, apesar de ser uma lei que visa regulamentar e nortear as interações na Rede, não exaure a necessidade de disposições mais específicas com previsões de sanções a respeito da proteção de dados. Nesse sentido é que o próprio art. $3^{\circ}$ do Marco Civil, em seu inciso III, menciona a necessidade de uma lei específica para a proteção de dados no Brasil ${ }^{116}$, a qual ainda não não foi aprovada pelo Congresso Nacional, não tendo o Brasil hoje uma norma específica sobre proteção de dados.

\footnotetext{
${ }^{116}$ DONEDA, Danilo; MONTEIRO, Marília. O sistema da privacidade e a proteção de dados no Marco Civil da Internet. In: ARTESE, Gustavo (Org.). Marco Civil da Internet: análise jurídica sob uma perspectiva empresarial. São Paulo: Quartier Latin, 2015. p. 76.
} 
Dessa forma, o Marco Civil, veio a ser um instrumento jurídico muito importante na tutela dos dados inseridos na Rede, contudo não se pode afirmar que este veio a ser de fato uma lei geral de proteção de dados no Brasil, matéria ainda pendente de análise pelo Congresso.

Desse modo é que atualmente existem diversas projetos de lei tramitando no Congresso que buscam regulamentar de maneira efetiva, com o estabelecimento de deveres e garantias dos usuários da Rede, o direito fundamental à privacidade resguardando-se a proteção dos dados obtidos por meio das novas tecnologias.

\subsubsection{O Marco Civil da Internet - Lei 12.965/2014}

O Marco Civil da Internet, Lei 12. 965/2014, é, na realidade a primeira iniciativa legislativa brasileira que se propõem a tratar dos relacionamentos na Rede e estabelece princípios e normas gerais a serem observadas nesse meio, tendo apresentado algumas previsões no que tange à privacidade e a proteção de dados.

A referida lei - cuja tramitação e aprovação se deram de forma acelerada após o escândalo de espionagem pelo Governo americano de alguns chefes de Estado, como foi o caso da então Presidente Dilma Rouseff - teve como preocupação principal o estabelecimento de algumas - poucas - disposições que buscam proteger à privacidade dos usuários na Rede, principalmente no que se refere à coleta de dados por sociedades empresárias. ${ }^{117}$

Nesse sentido, o Marco Civil estabeleceu como princípios em seu art. $3^{\circ}$ a proteção da privacidade e dos dados pessoais ${ }^{118}$ tendo também reafirmado em

\footnotetext{
${ }^{117}$ BARBOSA, Marco. Marco Civil da Internet: Mercado e Estado de Vigilância. In: LUCCA, Newton; FILHO, Adalberto Simão; LIMA, Cintia Rosa Pereira (Org.). Direito \& Internet III: Marco Civil da Internet (Lei 12.965/2014). Tomo II. São Paulo: Quartier Latin, 2015, p. 238.

${ }^{118}$ Art. $3^{\circ} \mathrm{A}$ disciplina do uso da internet no Brasil tem os seguintes princípios:

(...)

II - proteção da privacidade;

III - proteção dos dados pessoais, na forma da lei;
} 
seu artigo $7^{\circ}$, incisos I a III, o direito fundamental à privacidade instituído pela Constituição de 1988, com a inviolabilidade da intimidade, da vida privada e do sigilo dos fluxos de comunicação pela Internet e das comunicações armazenadas. ${ }^{119}$ Outro dispositivo nesse sentido é o art. $8^{\circ}$ que também prevê expressamente a garantia de proteção do direito da privacidade como sendo uma condição para o livre exercício do direito de acesso à internet. ${ }^{120}$

Desse modo, verifica-se que o Marco Civil da Internet, além de estabelecer outros princípios e normas gerais para o uso da Rede, como o princípio da neutralidade e o da preservação à liberdade de expressão, também teve como preocupação a proteção da privacidade e, por conseguinte, a proteção de dados, determinando serem invioláveis o sigilo e o fluxo de comunicações pela internet assim como as comunicações privadas e armazenadas.

Além disso, os artigos 10 a 12 prevêem regras de proteção de registros de conexão e aos registros de acesso à aplicações, determinando a necessidade de que o acesso à tais registros seja realizado por meio de ordem judicial. A respeito da necessidade de ordem judicial, esta somente deverá ser concedida quando estiverem presentes os requisitos do art. 22 do $\mathrm{MCI}^{121}$, que estabelece critérios pouco objetivos para o deferimento da medida, como a existência de fundado

\footnotetext{
${ }^{119}$ Art. $7^{\circ} \mathrm{O}$ acesso à internet é essencial ao exercício da cidadania, e ao usuário são assegurados os seguintes direitos:

I - inviolabilidade da intimidade e da vida privada, sua proteção e indenização pelo dano material ou moral decorrente de sua violação;

II - inviolabilidade e sigilo do fluxo de suas comunicações pela internet, salvo por ordem judicial, na forma da lei;

III - inviolabilidade e sigilo de suas comunicações privadas armazenadas, salvo por ordem judicial;

${ }^{120}$ Art. $8^{\circ} \mathrm{A}$ garantia do direito à privacidade e à liberdade de expressão nas comunicações é condição para o pleno exercício do direito de acesso à internet.

${ }^{121}$ Art. 22. A parte interessada poderá, com o propósito de formar conjunto probatório em processo judicial cível ou penal, em caráter incidental ou autônomo, requerer ao juiz que ordene ao responsável pela guarda o fornecimento de registros de conexão ou de registros de acesso a aplicações de internet. Parágrafo único. Sem prejuízo dos demais requisitos legais, o requerimento deverá conter, sob pena de inadmissibilidade:

I - fundados indícios da ocorrência do ilícito;

II - justificativa motivada da utilidade dos registros solicitados para fins de investigação ou instrução probatória; e

III - período ao qual se referem os registros.
} 
receio de ocorrência de um ilícito assim como no caso de auxílio à uma investigação ou instrução probatória em um processo.

Cumpre mencionar que o MCI também adotou em seu art. $7^{\circ}$ inciso VIII ${ }^{122}$ dois princípios que devem estar presentes quando se trata de proteção de dados. São eles o princípio da finalidade e o da transparência, tendo o MCI afirmado como direito do usuário receber informações claras e completas sobre a coleta, uso e armazenamento de seus dados, para determinadas finalidades.

Ainda, no já citado art. $7^{\circ}$, em seu inciso VII ${ }^{123}$, o Marco Civil buscou efetivar a tutela do direito à privacidade por meio do instituto do não fornecimento de dados sem o consentimento livre e informado do usuário da Rede. O referido inciso, buscando resguardar o direito à privacidade e que a coleta de dados não se dê de forma abusiva, com a comercialização de dados sem o consentimento de seu titular, estabeleceu que o fornecimento deve ser informado ao usuário, prevenindo-se que os dados sejam transferidos e comercializados, algo extremamente corriqueiro para os sites e aplicativos que lucram com os dados coletados fornecendo-os à terceiros para atender à interesses e finalidades que em nada se relacionam com a natureza do serviço prestado.

A questão do consentimento livre, expresso e informado, trata-se de questão bem complexa, visto que na prática a aferição desse consentimento é deveras questionável, principalmente no que tange o requisito de estar o usuário

\footnotetext{
${ }^{122}$ Art. $7^{\circ} \mathrm{O}$ acesso à internet é essencial ao exercício da cidadania, e ao usuário são assegurados os seguintes direitos:

VIII - informações claras e completas sobre coleta, uso, armazenamento, tratamento e proteção de seus dados pessoais, que somente poderão ser utilizados para finalidades que:

a) justifiquem sua coleta;

b) não sejam vedadas pela legislação; e

c) estejam especificadas nos contratos de prestação de serviços ou em termos de uso de aplicações de internet;

${ }^{123}$ Art. $7^{\circ} \mathrm{O}$ acesso à internet é essencial ao exercício da cidadania, e ao usuário são assegurados os seguintes direitos

VII - não fornecimento a terceiros de seus dados pessoais, inclusive registros de conexão, e de acesso a aplicações de internet, salvo mediante consentimento livre, expresso e informado ou nas hipóteses previstas em lei;
} 
devidamente informado a respeito da coleta, uso e armazenamento de seus dados pelos aplicativos que usa ou pelos sites que acessa.

Isso porque as denominadas "políticas de privacidade" e "termos de uso" da maioria de aplicativos e sites não apresenta de forma organizada e destacada as informações a respeito da coleta, uso e armazenamento dos dados dos usuários, o que torna difícil que o usuário tenha consciência plena de quais dados seus estão sendo coletados, a forma pela qual eles estão sendo coletados assim como para qual finalidade e por quanto tempo esses dados serão armazenados pelo site ou aplicativo.

A falta de conhecimento pelo titular dos dados é verificada por uma pesquisa conduzida pela FGV em conjunto do Conselho Europeu ${ }^{124}$, a qual demonstrou que apenas $20 \%$ das plataformas pesquisadas permitem que o usuário acesse uma cópia dos dados enviados a elas; uma em três "explicitamente afirmam que não permitirão ver e copiar os dados" e $38 \%$ nem informam sobre esse ponto.

Dessa forma, se verifica a total falta de atenção daqueles que coletam dados em informar os usuários a respeito da coleta que realizam assim como da impossibilidade do usuário de ter o conhecimento dos seus dados, o que obsta de forma absurda o direito à autodeterminação informativa. ${ }^{125}$

Tal situação se agrava tendo em vista que o MCI não estabeleceu formas de fiscalização e medidas efetivas que as sociedades empresárias precisam tomar no sentido de concretizar o princípio da privacidade e de proteção de dados. Assim, diante da ausência de uma regulamentação específica, diversas questões, como o que pode ser coletado, para qual finalidade e sobre quais agentes a

\footnotetext{
${ }^{124}$ VENTURINI, Jamila. et al..Terms of service and human rights: an analysis of online platform contracts. Disponível em: <http://hdl.handle.net/10438/18231>. Acesso em 25 de maio de 2018.

${ }^{125}$ A autodeterminação informativa é um conceito que transmite a ideia de o indivíduo participar ativamente na proteção de seus dados, permitindo o controle pelos próprios indivíduos sobre quais dados serão coletados, usados, armazenados e revelados. DONEDA, Danilo. Da privacidade à proteção de dados pessoais. Rio de Janeiro: Renovar. 2006. p 221. Nesse mesmo entendimento, Rodotà afirma ser a autodeterminação informativa "poder de controlar a circulação das próprias informações" permitindo que o indivíduo possa "construir livremente a própria esfera privada". RODOTÀ, Stefano. A vida na sociedade da vigilância. Rio de Janeiro: Renovar. 2007. p. 74.
} 
responsabilidade pelo descumprimento de determinações deve recair; permanecem em aberto, gerando uma insegurança jurídica muito grande para a sociedade.

Dessa forma é que a aprovação de uma lei de proteção de dados que seja produto de uma boa reflexão, bem redigida, com a definição de conceitos, com a previsão de direitos e deveres e como executá-los, bem como com a previsão de penalidades e sanções severas, se faz tão urgente no momento atual da sociedade.

Um último ponto a ser destacado para indicar a inadequação do MCI como uma lei de proteção de dados se dá pelo fato de o MCI ter a sua aplicação limitada às relações ocorridas dentro da Rede, não se aplicando por exemplo à coleta de dados que se dá sem o uso da Internet ${ }^{126}$. Além disso, o MCI não define alguns conceitos básicos para que se possa ter uma política efetiva de proteção de dados e privacidade.

Assim, é possível afirmar que hoje no Brasil se tem um microssitema de proteção de dados, com alguns diplomas legais como a Constituição Federal, o MCI, o Código de Defesa do Consumidor, a Lei do Cadastro Positivo (Lei ${ }^{\circ}$ 12.414/2011) e a Lei de Acesso à Informação (Lei no 12.527/2011), que fazem menção à privacidade e proteção de dados, mas não tratam da matéria de forma específica e fundamentada.

Nesse sentido é que o Congresso vislumbrou - ainda que muito tardiamente - a necessidade da existência de uma lei específica sobre proteção de dados principalmente daqueles coletados por meio das novas tecnologias - dando início à alguns projetos de lei que serão a seguir analisados.

\footnotetext{
${ }^{126}$ MACIEL, Rafael. Lei de proteção de dados e agência regulatória são fundamentais para o Brasil. Disponível em: <https://www.conjur.com.br/2017-ago-19/rafael-maciel-lei-protecao-dadosfundamental-brasil>. Acesso em: 25 de maio de 2018.
} 


\subsubsection{Demais iniciativas legislativas (PL 330/2013 e PL $5.276 / 2016)$}

Apesar da inexistência de uma lei específica sobre proteção de dados no Brasil, estando a proteção da privacidade e dos dados tutelados pela Constituição Federal e por algumas disposições gerais previstas pelo Marco Civil da Internet e demais leis não específicas sobre o assunto ${ }^{127}$, hoje já é possível afirmar a existência de alguns projetos de lei sobre proteção de dados tramitando no Congresso Nacional, dois deles que se encontram em maior evidência no momento. São eles os projetos de lei $N^{o}$ 330/2013, de iniciativa do Senado Federal, e N ${ }^{\circ} 5.276 / 2016$, de iniciativa do Poder Executivo.

O PL 330/2013, apresentado pelo Senador Antonio Carlos Valadares (PSB/ES) foi proposto dois meses após o caso Edward Snowden. Em 2015, ganhou substitutivo do senador Aloysio Nunes (PSDB/SP) e em maio de 2016, teve votação favorável pela Comissão de Meio Ambiente e Defesa do Consumidor, três dias antes da apresentação de uma versão da lei de dados pessoais pelo governo Dilma Rousseff ${ }^{128}$. O referido projeto também já foi objeto de parecer favorável pela Comissão de Assuntos Econômicos, após o qual foi requerida a inclusão do projeto para a sua apreciação pelo plenário em caráter de urgência, ainda não tendo sido estipulada uma nova data para a apreciação do projeto $^{129}$.

\footnotetext{
127 “Assim, a proteção de dados pessoais, compreendida de norma geral, há de ser objeto de um estatuto normativo específico que aborde a proteção de dados pessoais de forma geral, ao passo que as provisões de proteção de dados constantes no Marco Civil da Internet consistem de especificações que levam em consideração as características da Internet. DONEDA. Danilo. O Sistema da Privacidade e Proteção de Dados no Marco Civil da Internet. In: Artese, GUSTAVO. (Org.). Marco Civil da Internet: Análise Jurídica sob uma Perspectiva Empresarial. São Paulo: Quartier Latin, 2015. p. 76.

${ }^{128}$ ZANATTA, Rafael, et. al. O 'efeito Zuckenberg' no Senado: uma nova lei de proteção de dados no forno?. Disponível em: <https://www.jota.info/opiniao-e-analise/artigos/o-efeito-zuckerberg-nosenado-uma-lei-de-dados-no-forno-19042018>. Acesso em 27 de maio de 2018.

${ }^{129}$ Informações atualizadas até o dia 27 de Maio de 2018.
} 
Ressalta-se que este projeto de lei teve início no ano de 2013, isto é, há quase 5 anos atrás, contudo retomou a sua tramitação após o escândalo de fornecimento dos dados pelo Facebook à Cambridge Analytica, tendo a discussão sobre proteção de dados pessoais ganhado uma nova dimensão, impulsionando a tramitação do PL 330/13.

Pois bem. Pretende o referido projeto regular o tratamento e o uso de dados por pessoas naturais e jurídicas de direito público ou privado; apresentar definições para dados pessoais, dados sensíveis, banco de dados; tratamento de dados pessoais, gestor de banco de dados, titular de dados pessoais, entre outros; estabelecer a existência de uma autoridade fiscalizadora da proteção de dados; como também a prever a aplicação de sanções em caso de descumprimento de suas normas. ${ }^{130}$

Em primeiro lugar verifica-se que a especificação dos destinatário do projeto de lei é muito importante visto que neste rol se incluem as pessoas jurídicas de direito público, não se excepcionando a administração pública dos deveres e obrigações a serem estabelecidas em uma futura lei de proteção de dados.

Além disso, o referido projeto de lei também vislumbra a instituição de um órgão com competências para a regulamentação, fiscalização e sanção relacionadas à coleta, tratamento e uso de dados pessoais, o que é muito positivo para a efetiva observância das normas de proteção de dados a serem estabelecidas. Apesar de prever a instituição de tal órgão, o projeto não delimita as suas atribuições, nem trata de sua estrutura e natureza jurídica, motivo pelo qual a sua atuação como verdadeira autoridade fiscalizadora e garantidora da proteção de dados pode se mostrar precária diante dos fins pretendidos.

O PL 5.276/2016 se assemelha muito ao PL 330/2013 e também faz referência à um órgão competente para garantir a proteção de dados pessoais,

\footnotetext{
130 Informações retiradas no site do Senado Federal. Disponível em: <https://www25.senado.leg.br/web/atividade/materias/-/materia/113947>. Acesso em 27 de maio de 2018.
} 
sem especificar sua vinculação, composição e orçamento. A proposta estipula a criação de Conselho Nacional de Proteção de Dados Pessoais, de caráter consultivo e composto majoritariamente por representantes do governo - o que significa poucos assentos para representantes da sociedade civil e da iniciativa privada.

Do mesmo modo, o PL 5.276/2016 também apresenta um rol de definições de alguns conceitos como o conceito de dados pessoais, assim como especifica o âmbito de abrangência da lei de proteção de dados de forma mais minuciosa, estabelecendo as hipóteses de tratamentos e dados, os direitos dos usuários sobre os seus dados, assim como estabelece sanções e aborda a instituição de uma autoridade fiscalizadora, como já mencionado. ${ }^{131}$

Assim como o PL 330/2013, o PL 5.276/2016 também determina a aplicabilidade de suas normas sobre tratamento de dados para as pessoas naturais e as pessoas jurídicas de direito público ou privado, incluindo o Estado no que se refere às normas sobre proteção de dados. Nesse ponto, contudo, Roberto Picceli faz uma ressalva ao notar que o referido projeto de lei, em seu art. $4^{\circ}$, inciso III, excetua a observância das normas sobre proteção de dados pra fins de preservação da "segurança pública, de defesa nacional, de segurança do Estado ou de atividades e repressão de infrações penais.”. Ora, como não poderia deixar de ser, tal ressalva à aplicação de normas de proteção de dados é muito criticada por parte da doutrina, que alega a sua inconstitucionalidade patente, tendo em vista configurar tal dispositivo uma exceção à proteção da privacidade e dos dados realizada por lei sem que o próprio constituinte, em seu art. $5^{\circ}$ incisos $\mathrm{X}$ e XII, tenha previsto tal exceção.

Aliás, o argumento de manutenção e preservação da segurança pública para fundamentar a permissão de condutas que violem a proteção de dados e a proteção do direito fundamental à privacidade como um todo vem sendo muito

\footnotetext{
${ }^{131}$ PICCELLI, Roberto Ricomini. A dimensão política da privacidade no direito brasileiro. Rio de Janeiro: Lumen Juris, 2018. p. 142.
} 
utilizado, tornando frágil e deficiente a futura de lei de proteção e dados no Brasil.

Isso porque, como já mencionado acima, o próprio constituinte não fez qualquer ressalva quanto à proteção do direito à privacidade com base na segurança pública, bem como pelo fato de que o uso de tais termos - "segurança pública", "defesa nacional", etc. - podem ser, no caso concreto, enquadrados de forma um tanto quanto subjetiva, diminuindo o grau de proteção dos usuários sobre os seus dados e a sua privacidade. ${ }^{132}$

A respeito da instituição de uma autoridade garantidora da observância das normas sobre proteção de dados, há de se destacar também que o projeto, até o momento, não definiu a sua natureza jurídica e, consequentemente, o seu grau de vinculação com a Administração Pública.

Entende-se que é necessário um certo grau de independência desse órgão para com a Administração, principalmente para garantir a aplicação e adoção das medidas pelo Estado.

Contudo, também não deve ser o órgão desvinculado totalmente da Administração vez que a ausência do Estado pode acarretar na preponderância de interesses de agentes meramente privados, frustrando o objetivo principal da possível lei de proteção de dados, que é a proteção da privacidade sob uma concepção coletiva.

Assim, analisados os principais projetos de lei sobre proteção de dados no Brasil, ainda que de forma superficial, é possível identificar a preocupação do legislador brasileiro em definir conceitos, estabelecer hipóteses e condutas permitidas e não permitidas quanto o tratamento de dados, assim como em estabelecer uma autoridade fiscalizadora sobre a coleta, armamento, uso e armazenamento de dados.

${ }^{132}$ Ibid, p. 143 . 
O PL 330/13 será, ao que tudo indica, a lei específica sobre proteção de dados no Brasil, visto que a sua tramitação vem se dando de forma mais acelerada do que a tramitação do PL 5.276/2016. 


\section{Conclusão}

No presente trabalho se buscou analisar o surgimento das novas tecnologias e ascendência da sociedade da informação e das suas implicações para o direito fundamental à privacidade, direito previsto constitucionalmente.

Isso porque os dados, e, consequentemente, as informações coletadas na Rede se tornaram um ativo muito valioso para o mercado atual, assim como para os Governos, motivo pelo qual se verificou a sua coleta, tratamento e armazenando de formas abusivas e sem o conhecimento do titular dos dados produzidos, gerando uma prática de violação reiterada de dados e do direito à privacidade dos usuários da Rede.

A respeito do direito à privacidade, se observou nessas últimas décadas uma transformação desse direito, o qual foi primeiramente concebido sob uma perspectiva individualista para hoje ser entendido sob uma ótica coletiva, na qual a sua proteção não diz mais respeito apenas à proteção de interesses de um único indivíduo, mas sim sobre a sociedade como um todo.

Nesse sentido, é que se observou um movimento da sociedade - e do direito - em buscar soluções para as novas questões que se colocaram. Assim, é que se tornou necessário que os ordenamentos jurídicos, em escala mundial, adotassem medidas regulatórias de proteção de dados, com o intuito de impedir a violação à privacidade de seus indivíduos, motivo pelo qual surgiram diversos diplomas legais estrangeiros os quais buscaram estabelecer meios de proteção contra a coleta abusiva de dados, estabelecendo certas diretrizes a serem observadas, medidas práticas a serem adotadas, assim como a instituição de um órgão fiscalizador.

Sobre os modelos regulatórios adotados, destacou-se o modelo europeu, com a introdução da mais nova e relevante norma sobre o tema, o GDPR - 
General Data Protection Regulation que, ao que tudo indica resultará na mudança de comportamento da maioria dos agentes privados e de agentes públicos no que tange à coleta e tratamento de dados. A mencionada regulação se mostra ser, em seu texto, um diploma legal bem rígido e sério quanto à proteção de dados de cidadãos europeus, inclusive para além da Europa, resultando numa preocupação e adequação mundial das empresas à esse novo regulamento.

Tratando do Brasil, é fato que o país ainda não detém qualquer lei específica de aplicabilidade geral sobre a proteção de dados, tendo hoje uma variedade de diplomas normativos que abordam de forma breve a proteção de dados e o direito à privacidade. Entretanto, relembrou-se que tais leis não se tratam de uma lei específica de proteção dados, tratando apenas de questões acessórias e aplicáveis à matéria principal do texto normativo.

Ressalta-se que o MCI foi uma tentativa mais geral e um pouco mais específica sobre proteção de dados existente no ordenamento. Contudo, o MCI não pode ser entendido como uma lei de proteção de dados vez que não definiu conceitos mínimos para a sua proteção, não previu medidas efetivas a serem adotadas por aqueles que coletam e tratam dados, assim como não prevê sanções a serem aplicadas pela autoridade fiscalizadora - a qual ainda não existe - ante o descumprimento de uma de suas normas.

Dessa forma e, considerando os atuais eventos envolvendo de venda e vazamento de dados, é que o debate sobre a elaboração de uma lei de proteção de dados para o ordenamento jurídico brasileiro se faz tão essencial, visto que a regulação é pressuposto da manutenção de direitos. 


\section{Bibliografia}

ALlEN, Anita L. Protecting One's Own Privacy in a Big Data Economy. Law, Privacy \& Technology Commentary Series. Harvard Law Review. Vol. 130, No. 2, Dec. 2016.2 Disponível em: $<$ https://harvardlawreview.org/2016/12/protecting-ones-own-privacy-in-a-bigdata-economy/>. Acesso em 20 de janeiro de 2018.

BALKIN, Jack M. Free Speech in the Algorithmic Society: Big Data, Private Governance, and New School Speech Regulation. UC Davis Law Review; Yale Law School, Public Law Research, No. 615. set. 2017.

BARBOSA, Marco A.. Marco Civil da Internet: Mercado e Estado de Vigilância. In: LUCCA, Newton; FILHO, Adalberto Simao; LIMA, Cintia Rosa Pereira (Org.). Direito \& Internet III: Marco Civil da Internet (Lei 12.965/2014). Tomo II: São Paulo: Quartier Latin, 2015, p. 233-250.

BARBOSA, Pedro Marcos Nunes. E-stabelecimento: teoria do estabelecimento comercial na internet, aplicativos, websites, segregação patrimonial, trade dress eletrônico, concorrência online, ativos intangíveis cibernéticos e negócios jurídicos. São Paulo: Quartier Latin, 2018. 351 p.

BARROSO, Luis Roberto. Colisão entre Liberdade de Expressão e Direitos da Personalidade. Critérios de Ponderação. Revista de Direito Administrativo. Rio de Janeiro, v. 235, p. 1-36, jan. 2004. <http://bibliotecadigital.fgv.br/ojs/index.php/rda/article/view/45123/45026>. Acesso em 28 de outubro 2017. 
BENKLER, Yochai. The Wealth of Networks: How Social Production Transforms Markets and Freedom. Yale University Press, 2006. 515 p.

BENTHAM, Jeremy. O Panóptico. $2^{\mathrm{a}}$ ed. Organização de Tomaz Tadeu; Trad. de Guacira Lopes Louro, M. D. Magno, Tomaz Tadeu. Belo Horizonte: Autêntica Editora, 2008. 201 p.

BINENBOJM, Gustavo. Poder de polícia, ordenação, regulação: transformações político-jurídicas, econômicas e institucionais do direito administrativo ordenador. Belo Horizonte: Fórum, 2016. 380 p.

BITTAR, Carlos Alberto. Os direitos da personalidade. $2^{\mathrm{a}}$. ed. rev. e atual. Rio de Janeiro: Forense, 1999. 248 p.

BOBBIO, Norberto. A Era dos Direitos. trad. Carlos Nelson Coutinho; apresentação de Celso Lafer. $7^{\mathrm{a}}$ reimpressão. Rio de Janeiro: Elsevier, 2004. 97 p.

CASTELLS, Manuel. A sociedade em rede. $18^{\mathrm{a}}$ ed. Tradução de Roneide Venancio Majer. São Paulo: Paz e Terra, 2017. 629 p.

Constituição da República Federativa do Brasil de 1988. Disponível em: <http://www.planalto.gov.br/ccivil_03/constituicao/constituicao.htm>. Acesso em 29 de maio de 2018.

COSTA, Camilla. Como descobrir o que o Facebook sabe sobre você. Disponível em <http://www.bbc.com/portuguese/geral-43493673>. Acesso em 04 de abril de 2018. 
Declaração Universal de Direitos Humanos da ONU. Disponível em: <http://www.onu.org.br/img/2014/09/DUDH.pdf>. Acessado em 28 de outubro de 2017.

DIEBOLD, Francis X. On the Origin(s) and Development of the Term 'Big Data'. PIER Working Paper No. 12-037, PENN Institute for Economic Reserach, Setembro de 2012.

Diretiva 95/46/CE. Disponível em: <https://eur-lex.europa.eu/legalcontent/PT/TXT/PDF/?uri=CELEX:31995L0046\&from=PT>. Acesso em $28 \mathrm{de}$ Maio de 2018.

DONEDA, Danilo. O Direito Fundamental à Proteção de Dados Pessoais. In: MARTINS, Guilherme Magalhães (Org.). Direito Privado e Internet. São Paulo: Editora Atlas, 2014. p. 61-78.

DONEDA, Danilo. Da privacidade à proteção de dados pessoais. Rio de Janeiro: Renovar, 2006. 448 p.

DONEDA, Danilo; MONTEIRO, Marília. O Sistema da Privacidade e Proteção de Dados no Marco Civil da Internet. In: ARTESE, Gustavo (Org.). Marco Civil da Internet: análise jurídica sob uma perspectiva empresarial. São Paulo: Quartier Latin, 2015. p. 73-96.

ELIAS, Norbert. A Sociedade dos Indivíduos. Rio de Janeiro: Jorge Zahar Ed. 1994. 204 p.

FILHO, Eduardo Tomasevicius. O Marco Civil da Internet e as Liberdade de Mercado. In: LUCCA, Newton; FILHO, Adalberto Simão; LIMA, Cintia Rosa 
Pereira (Org.). Direito \& Internet III: Marco Civil da Internet (Lei 12.965/2014). Tomo II. São Paulo: Quartier Latin, 2015. p. 49-64.

FISHER III, William W. Promises to Keep: Technology, Law, and the Future of Entertainment. California: Stanford University Press, 2004. 340 p.

FORGIONI, Paula A.; MIURA, Maira Yuriko Rocha. O Princípio da Neutralidade e o Marco Civil da Internet no Brasil. In: LUCCA, Newton; FILHO, Adalberto Simão; LIMA, Cintia Rosa Pereira (Org.). Direito \& Internet III: Marco Civil da Internet (Lei 12.965/2014). Tomo II. São Paulo: Quartier Latin, 2015. p. 109-135.

FOUCAULT, Michel. Vigiar e punir: nascimento da prisão. $36^{\mathrm{a}}$ ed. Trad. Raquel Ramalhete. Petrópolis: Vozes, 2009. 288 p.

GRAU, Eros Roberto. A Ordem econômica na Constituição de 1988 (Interpretação e crítica). 14ª ed. São Paulo: Malheiros Editores, 2010. 391 p.

GUIDI, Guilherme Berti de Campos. Modelos regulatórios para proteção de dados pessoais. Disponível em: <https://itsrio.org/wpcontent/uploads/2017/03/Guilherme-Guidi-V-revisado.pdf>. Acesso em 17 de maio de 2018.

HUNT, Lynn. A invenção dos direitos humanos: uma história. Trad. Rosaura Eichenberg. São Paulo: Companhia das Letras, 2009. 288 p.

KEEN, Andrew. Vertigem Digital: Por que as redes sociais estão nos dividindo, diminuindo e desorientando. Tradução Alexandre Martins, Editora Zahar, 2012. $256 \mathrm{p}$. 
LEMOALLE, Edouard; CARBONI, Guilherme. Lei Europeia de Proteção de Dados Pessoais (GDPR) e seus efeitos no Brasil. Disponível em $<$ https://www.jota.info/opiniao-e-analise/artigos/lei-europeia-de-protecao-dedados-pessoais>. Acesso em 19 de maio de 2018.

LEONARDI, Marcel. Tutela e privacidade na Internet. São Paulo: Saraiva, 2011. 402 p.

LESSIG, Lawrence. Code Version 2.0. Nova Iorque: Basic Books, 2006. 410 p.

LÉVY, Pierre. Cibercultura. $3^{\text {a }}$ ed. Tradução de Carlos Irineu da Costa, São Paulo: Editora 34, 2011. 270 p.

LOCKE, John. O Segundo Tratado sobre o Governo Civil. Tradução: Magda Lopes e Marisa Lobo da Costa. Petrópolis: Editora Vozes, 1994. 103 p.

LONGHI, João Victor Rozatti. Marco Civil da Internet no Brasil: Breves considerações sobre seus fundamentos, princípios e análise crítica do regime de responsabilidade civil dos provedores. In: MAGALHÃES, Guilherme Martins (Org.). Direito Privado e Internet. São Paulo: Editora Atlas, 2014. p 109-145.

LOURENÇO, Cristina Sílvia Alves; GUEDES, Maurício Sullivan Balhe. A internet e o direito à exclusão de dados pessoais na experiência brasileira. In: LEITE, George Salomão; LEMOS, Ronaldo (Org.). Marco Civil da Internet. São Paulo: Atlas, 2014. p 559 -573.

MACIEL, Rafael. Lei de proteção de dados e agência regulatória são fundamentais para o Brasil. Disponível em: <https://www.conjur.com.br/2017- 
ago-19/rafael-maciel-lei-protecao-dados-fundamental-brasil>. Acesso em: 25 de maio de 2018

MAGRANI, Eduardo. Democracia conectada: a internet como ferramenta de engajamento político-democrático. Curitiba: Juruá, 2014. 222 p.

MARMELSTEIN, George. Curso de Direitos Fundamentais. $4^{\mathrm{a}}$ ed. São Paulo: Atlas, 2008. $584 \mathrm{p}$

MARTINS, Guilherme Magalhães. Responsabilidade civil por acidente de consumo na internet. São Paulo: Editora Revista dos Tribunais, 2014. 448 p.

MIRANDA, Francisco Cavalcanti Pontes de. Tratado de direito privado. Atual. Vilson Rodrigues Alves. 2a . ed. Campinas: Bookseller, 2000. 509 p.

MOLINARO, Carlos Alberto; SARLET, Ingo Wolfgang. Breves notas acerca das relações entre Sociedade em Rede, a Internet e o assim chamado Estado de Vigilância. In: LEITE, George Salomão; LEMOS, Ronaldo (Org.). Marco Civil da Internet. São Paulo: Editora Atlas, 2014. p. 29-48.

MORAIS, José Luis Bolzan de; NETO, Jacob de Menezes. A insuficiência do Marco Civil da Internet na proteção das comunicações privadas armazenadas e do fluxo de dados a partir do paradigma da Surveillance In: LEITE, George Salomão; LEMOS, Ronaldo (Org.). Marco Civil da Internet. São Paulo: Editora Atlas, 2014. p. 417-439.

PÁDUA, Luciano. Sorria? Seus dados estão sendo compartilhados. Disponível em: <https://www.jota.info/coberturas-especiais/liberdade-de-expressao/sorriadados-compartilhados-29032018>. Acesso em 04 de abril de 2018. 
PERLINGIERI, Pietro. Perfis do Direito Civil Introdução ao Direito Civil Constitucional. Trad. Maria Cristina de Cicco. $2^{\mathrm{a}}$. ed. Rio de Janeiro: Renovar, 2008. $340 \mathrm{p}$.

PICCELLI, Roberto Ricomini. A dimensão política da privacidade no direito brasileiro. Rio de Janeiro: Lumen Juris, 2018. 171 p.

RODOTÀ, Stefano. A vida na sociedade de vigilância: a privacidade hoje. Rio de Janeiro: Renovar, 2008. 382 p.

RODOTÀ, Stefano. Il terribile dirrito. Studi sulla proprietà privata e i beni comuni. Bologna: Il Mulino, 2013. 514 p.

SCHERKERKEWITZ, Iso Chaitz. Direito e Internet. São Paulo: Revista dos Tribunais, 2014. $171 \mathrm{p}$.

SCHREIBER, Anderson. Direitos da Personalidade. São Paulo: Atlas, 2011. $275 \mathrm{p}$.

SILVA, José Afonso. Curso de Direito Constitucional Positivo. $37^{\mathrm{a}}$ ed. São Paulo: Malheiros, 2014. 934 p.

SINGER, Joseph William. No Freedom Without Regulation: The Hidden Lesson of the Subprime Crisis. Londres: Yale University Press, 2015. 224 p.

SOUSA, Rabindranath Capelo de. $O$ direito geral da Personalidade. $1^{\text {a }}$ ed. (Reimpressão) Coimbra: Coimbra Editora, 2011. 708 p. 
SOUZA, Carlos Affonso; LEMOS, Ronaldo. Marco Civil da Internet: Construção e Aplicação. Juiz de Fora: Editar Editora Associada Ltda., 2016. 153 p.

TENE, Omar; POLONETSKY, Jules. Privacy in the Age of Big Data: A Time for Big Decisions. Stanford Law Review, 64 Stan. L. Rev. Online 63. Fevereiro de 2012. Disponível em < https://www.stanfordlawreview.org/online/privacyparadox-privacy-and-big-data/. Acesso em: 29 de maio de 2018.

VENTURINI, Jamila. Terms of service and human rights: an analysis of online platform contracts. Disponível em<http://hdl.handle.net/10438/18231>. Acesso em 25 de maio de 2018.

VAIDHYANATHAN, Siva. The Googlization of everything: (and why we should worry). Los Angeles: University of California Press, 2011. 265 p.

WACHOWICZ, Marcos. Os impactos das novas tecnologias da informação. Revista do Direito, Santa Cruz do Sul, p. 54-89, jul. 2007. Disponível em: $<$ https://online.unisc.br/seer/index.php/direito/article/view/182/141>. Acesso em: 02 de maio 2018.

WARREN, Samuel D.; BRANDEIS, Louis D.. The Right to Privacy. Harvard Law Review, vol. 4, no. 5, 1890, pp. 193-220. JSTOR, <www.jstor.org/stable/1321160〉. Acessado em 30 de outubro de 2017.

ZANATTA, Rafael, et al.. 'O 'efeito Zuckenberg' no Senado: uma nova lei de proteção de dados no forno?”. Disponível em: <https://www.jota.info/opiniaoe-analise/artigos/o-efeito-zuckerberg-no senado-uma-lei-de-dados-no-forno19042018>. Acesso em 27 de maio de 2018. 